Acta vet. scand. $1976,17,153-168$.

From the Department of Clinical Radiology, the Department of Pathology and the Department of Surgery, Royal Veterinary College, Stockholm, Sweden, and the Laboratory for Comparative Orthopaedics, Hospital for Special Surgery, affiliated with the New York Hospital Cornell University Medical College, New York, N.Y., USA.

\title{
LIGHT AND ELECTRON MICROSCOPIC INVESTIGATION OF EQUINE SYNOVIAL MEMBRANE
}

\author{
A COMPARISON BETWEEN HEALTHY JOINTS AND JOIN'TS \\ WITH INTRAARTICULAR FRACTURES AND OSTEOCHON- \\ DROSIS DISSECANS *
}

\author{
By \\ Hans-Erik Johansson and Sven Rejnö
}

\begin{abstract}
JOHANSSON, HANS-ERIK and SVEN REJNÖ: Light and electron microscopic investigation of equine synovial membrane. A comparison between healthy joints and joints with intraarticular fractures and osteochondrosis dissecans. Acta vet. scand. 1976, 17, 153-168. - Light and electron microscopic examination was made on equine synovial membrane from 23 healthy joints, nine joints with synovitis caused by intraarticular fracture and 10 joints with synovitis caused by osteochondrosis dissecans. Histologically as well as ultrastructurally the equine synovial membrane from healthy joints was of principally the same character as described in other species. Three types of synovial membrane - areolar, fibrous and adipose - and two types of lining cell were distinguished histologically. Ultrastructurally three types of lining cells were distinguished: $A$ and $B$ type and an intermediate cell type. In healthy joints they were loosely arranged, parallel to the joint surface in an intercellular matrix, which was in direct continuity with the joint space. In joints with intraarticular fracture there was mild inflammation of the synovial membrane. There was elongation and hyperplasia of the lining cells with a relative increase in type A cells. The cell surface of lining cells was increased through filopodia. There was also an increase in cytoplasmic organelles i.e. hyperplasia of rough endoplasmic reticulum and Golgi complexes in $B$ type cells and an increase in lysosomes, and increased numbers of vesicles of varying types in $A$ cells. In joints with osteochondrosis dissecans the lining cell hyperplasia and the inflammation in the

* This study was supported by grants from professor Gerhard Forssell's stipendiefond, Virginska fonden, Jordbrukets försäkringsbolag, Sveriges Veterinärförbunds forskningsfond, the John M. Olin Foundation, H. C. Lagers stipendiefond and Anslaget för främjande av ograduerade forskares vetenskapliga verksamhet.
\end{abstract}


synovial membrane were more prominent. Ultrastructurally the same alterations as in the previous group were seen including a relative increase in the number of A cells but degenerative changes were common in the lining cells. These changes were dilatation and vesiculation of rough endoplasmic reticulum, mitochondrial condensation, dilatation of the nuclear envelope and loss of plasma membranes, leading to disintegration of cells.

horse; synovial membrane; synovitis; histology; ultrastructure.

The synovial fluid is considered a dialysate of bload with additional components (mainly hyaluronic acid) provided by the synovial membrane (i. a. Lever \& Ford 1959, Persson 1971).

The prevailing opinion is that the bulk of articular cartilage derives its nourishment from the synovial fluid (i. a. Bauer et al. 1940). The articular cartilage metabolism and joint lubrication is dependent on the synovial fluid produced by the synovial membrane. Thus the latter plays an important role in joint diseases of different types. Most joint diseases in the horse and other species are reflected in alterations in the joint capsule and in the synovial fluid. This is manifested clinically by lameness and distension of the joint capsule due to an increased volume of synovial fluid. Synovial fluid analyses (Nilsson \& Persson 1973) and histologic examinations of synovial membrane specimens often give only minor information on the joint lesions involved. Nilsson \& Olsson (1973) stated: "It is obvious from the present investigation that more refined techniques both in sampling and in examinations of the synovial membrane are necessary to determine the nature of the pathologic changes in this tissue".

Ultrastructural investigations on equine synovial membrane do not seem to have been reported in the available literature. The aim of the present investigation was to study the morphologic changes in synovial membrane from joints with synovitis by means of light and electron microscopy.

\section{REVIEW OF LITERATURE}

The joint capsule is composed of a stratum fibrosum and a stratum synoviale (synovial membrane). The synovial membrane lines the fibrous capsule and intraarticular ligaments and tendons. It is considered to consist of two tissue layers: A lining or intimal layer, next to the joint cavity, and a subintimal (also termed the subsynovial) layer. The intima is predominantly cel- 
lular with an abundant blood supply, while the subintimal layer is less vascular and cellular but rich in fibres (Barnett et al. 1961). According to the nature of the subintimal layer it has been classified into three categories: areolar, fibrous and adipose (Key 1932).

The synovial lining cells have been classified differently by different investigators. Nilsson \& Olsson (1973) found three intimal cell types of horse synovial membrane, one (C) which occurred predominantly in fibrous synovial membrane and two (A and B) seen in areolar and fatty synovial membrane.

The ultrastructure of synovial membrane has been described in several animal species. The lining layer forms a margin of cells, two-three cells in depth, merging gradually with the underlying connective tissue. The cells are loosely arranged. In many places the intercellular space is in direct continuity with the joint cavity. Cytoplasmic processes of the lining cells are usually directed towards the membrane surface. In most areas the processes overlap to form a loose network. Occasionally the processes are closely apposed to each other and interdigitations are sometimes seen (Ghadially \& Roy 1969). Two cell types (A and $B$ ) lining the synovium have been described in the human (i. a. Barland et al. 1962). Type $A$ is more numerous and contains prominent Golgi apparatus, numerous vacuoles with varying amounts of a dense granular material, many filopodia, mitochondria, intracellular fibrils, and micropinocytotic-like vesicles. Type B cells contain few large vacuoles, micropinocytotic-like vesicles and mitochondria, but have a well developed endoplasmic reticulum. Some authors prefer to call the $A$ and $B$ cells $M-$ and F-cells, respectively, as they resemble macrophages and fibroblasts (i. a. Hirohata \& Morimoto 1971).

Lever \& Ford (1959) found it impossible to distinguish clearly between fibroplasts in the synovial stroma and the cells lining the surface of the membrane. Schumacher (1968) also described cells which were characterized as intermediate between cells of type $A$ and $B$.

The ultrastructure of synovial tissue from rabbit, cat and man was examined by Lever \& Ford and was found to be principally of the same character. Davies \& Palfrey (1966) described the ultrastructure of synovial membrane from rabbits. The surface cells showed the same features as were described in other species, but a distinction between two morphological types, A 
and B could not be made. Synovial tissue from calf, dog and guinea pig was examined by Langer \& Huth (1960). They described a basement membrane, which has not been reported elsewhere. They found no important differences between the three species.

Roberts \& Ramsey (1969) described the electron microscopic findings in synovial tissue from normal pigs. They found three types of lining cells. According to their description two of the cell types corresponded to the type $A$ and the type $B$ cells. The third type of cells had relatively fewer cytoplasmic organelles. Synovial lining cells with characteristics similar to type A and $B$ cells, intermediate-type cells and undifferentiated cells were described in the sheep by Cutlip \& Cheville (1973).

A number of experimentally induced changes in the synovial membrane have been described in different species. Among others, infectious, immunological and physical methods have been employed. Cutlip (1974) reported that the alterations in structure of lining cells in the sheep after inoculation with chlamydia psittacci were indicative of a maturation of undifferentiated cells to type B cells and finally to type A cells. Elongation and hypertrophy of surface cells were seen as well as a more developed endoplasmic reticulum within the cells. In immunologically induced arthritis in rabbits Cherney (1971) found polymorphonuclear cell infiltration, edema, cellular damage and vascular congestion. Zichner \& Engel (1971) damaged the synovial membrane by ultrasonic radiation. After this treatment gross pathologic changes developed. "The lining cells stood vertical to the synovial membrane surface and not parallel as normally". The cell nuclei showed deep lobulation, folding and segmentation. The cellular edges became intensely serrated but did not interlock with each other. Vacuole formation became a prominent feature of the cytoplasm. Bhawan et al. (1973) studied the ultrastructure of synovial membrane in experimental pyogenic arthritis in rabbits. They showed bacterial phagocytosis by synovial cells and considered the synovial cell as a part of the reticuloendothelial system, able to play an important role in the body defense mechanism.

The ultrastructure of synovial membrane from human patients with pseudogout (Schumacher), synovitis of recent onset (Schumacher \& Kitridou 1972) and rheumatoid arthritis (i. a. Barland et al. 1964, Hirohata \& Kobayashi 1964, Norton \& 
Ziff 1966 and Auböck et al. 1974) has been described. Ultrastructural investigations on synovial membrane from animals with joint disease have not been reported. However, certain alterations seem to be in common in many different types of experimentally induced lesions and in lesions caused by disease in man. There are increased numbers of synovial cells, elongation of synovial cells and the cell surfaces become irregular in outline with many filopodia. An increased number of large vacuoles and vesicles are seen. Increased numbers of inflammatory cells are also frequently reported. It is not certain whether alterations in the vascular bed of diseased synovial tissue occur. Some authors report vascular changes (i. a. Cherney, Bierther \& Streit 1971, Schumacher \& Kitridou), but Brånemark et al. (1969) did not find any significant vascular changes when comparing the ultrastructural pattern of rheumatoid synovium to normal synovium.

Roy \& Ghadially (1967) treated rabbit synovial membrane specimens with colloidal iron, which is a specific stain for acid mucopolysaccharides. Under the electron microscope it was shown that iron particles were localized in the Golgi complexes and some larger smooth-walled vesicles of synovial cells. As a result of this study it was concluded that hyaluronic acid is probably synthesized in the Golgi complex of synovial cells. Ball et al. (1964) injected iron dextran into the knee joints of rabbits. There was a rapid uptake of iron dextran in the vacuolar type of lining cell but not in the endoplasmic reticulum type of cell. This was thought to indicate that the latter type of cell is mainly concerned with synthesis. Muirden (1963) injected ferritin into the knee joints of rabbits. The ferritin was demonstrated between and in intimal cells. It was concluded that the intimal cells (predominantly vacuole-containing type) play an important role in absorption from the joint cavity and in the transport of macromolecules into and out of cells.

\section{MATERIAL AND METHODS}

Twenty-three clinically healthy joints from 17 horses were chosen as controls: seven fetlock, 12 hock and four stifle joints. At clinical examination the horses displayed no signs of general disease and no signs of disease in the joints, from which material for examination was taken. Ten horses were standardbred trotters between two and 10 years of age and seven were Swe- 
dish half bred horses between three and 12 years. Standard methods for clinical examination were used (Strömberg \& Rejnö 1976).

Biopsy material from diseased joints was obtained from 19 joints of 18 horses: eight fetlock, seven hock and four stifle joints. Sixteen were standardbred trotters between seven months and 10 years of age. Two were Swedish halfbred horses, eight and 12 years old. The horses were referred to the clinics of the Veterinary College for examination of lameness and/or surgical treatment of intraarticular fractures. Samples were taken from nine joints with synovitis caused by intraanticular fracture with a duration of less than two weeks. Samples from joints with synovitis of more than three months' duration caused by osteochondrosis dissecans were obtained from 10 joints.

Synovial membrane specimens for histologic and ultrastructural examination were taken either at the surgical procedure under general anesthesia or with a biopsy needle according to Parker \& Pearson (1963). Specimens for histologic examination were fixed in $10 \%$ neutral formalin, embedded in paraffin and cut in $3-4 \mu$ thick sections. They were stained with hematoxylin-eosin, Alcian-PAS, PTAH, Ladevig's method for fibrin and Perl's method for iron. Specimens for ultrastructural examination were fixed in $3 \%$ glutaraldehyde buffered with $0.067 \mathrm{M}$ cacodylate buffer, $\mathrm{pH} 7.4$, postfixed in $2.67 \% \mathrm{OsO}_{4}, 0.067 \mathrm{M}$ s-collidine buffer and embedded in Epon. Sectioning was done with a LKB Ultrotome. The specimens were mounted on uncoated copper-grids. Contrast medium was uranyl acetate and lead citrate. The specimens were examined in a Philips RA 201 Electron Microscope. Epon-embedded $1 \mu$ thick sections were also stained with toluidine blue and examined under light microscope.

\section{RESULTS}

\section{Light microscopic examination}

Healthy joints

Synovial membrane from control joints was found to consist principally of two tissue layers. Next to the joint cavity was the lining or intimal layer, gradually merging into the underlying subintimal layer (Fig. 1).

The subintimal layer of the synovial membrane was either of areolar, adipose or fibrous type. The areolar type was charac- 
terized by loose connective tissue, the adipose type by adipose tissue and the fibrous type by fibrous connective tissue. In all types of synovial membrane there were sparse macrophages and lymphocytes and occasional mast cells in the subintimal layer (Fig. 1).

The lining layer consisted of two types of lining cells and was generally one to three cells in depth. T y p e 1 cells dominated areolar and adipose synovial membrane. The cytoplasm was abundant and the nucleus was lighter than in the cells of type 2. The chromatin was concentrated around the nuclear edges (Figs. 1 and 2). T y p e 2 cells were spindleshaped and resembled fibrocytes in the subintimal layer. This type of cell was present at sites with fibrous synovial membrane (Fig. 3).

\section{Joints with synovitis caused by intraarticular fracture}

Histologic changes in this group were characterized by inflammation. There was edema of synovial villi and increased number of lining cells. The lining cells were in general elongated with the nucleus at the deep pole and the cytoplasm directed towards the joint cavity (Fig. 4). In some specimens there were, between the lining cells, small deposits of fine amorphous eosinophilic material, which was negative for fibrin according to Ladevig's method. Free erythrocytes were seen in the joint space between villi.

Erythrocytes were seen to be phagocytized by intimal cells. Slight infiltration of mononuclear inflammatory cells was seen in the subintimal layer. Occasionally multilaminated basal lamina were seen around subintimal blood vessels.

\section{Joints with synovitis caused by osteochondrosis dissecans}

In this group more pronounced inflammatory changes were noticed. There was edema, increased vascularization and increased numbers of lining cells in the synovial villi. Elongation of synovial lining cells was a prominent feature. The cytoplasm contained many vacuoles and numerous processes directed into the joint cavity, giving the intimal layer a shaggy appearance (Figs. 5-7). In some specimens there were hemosiderin deposition (Perl staining) in macrophages in the subintimal layer (Fig. 6). Around some blood vessels there were aggregates of lymphocytes, plasmacells and macrophages (Fig. 6). 
However, in both groups of pathologic joints there were areas of apparently normal synovial tissue and of pathologic structures in the same joint.

\section{Electron microscopic examination Healthy joints}

The electron microscopic investigation was concentrated on the synovial intimal layer from predominantly areolar synovial membrane.

The lining cells were loosely arranged parallel to the membrane surface and were set in a slightly electron dense intercellular matrix. Filopodia mainly directed towards the joint space formed a network. Cell junctions were seen occasionally. The intercellular substance was slightly flocculent and contained a few collagen fibres. The intercellular space was often in direct continuity with the joint space (Fig. 8).

Two distinct types of lining cells (A and $B$ ) and an intermediate cell type were distinguished. Type A cells (Fig. 10) were less common than type B cells and were characterized by prominent Golgi complexes, numerous smooth walled vesicles, and a few coated vesicles, abundant mitochondria but sparse rough endoplasmic reticulum (RER). Microfilaments were frequently seen adjacent to the nucleus. The cytoplasm was more electron dense than in type B cells. Small vesicles containing electron dense material were seen in the Golgi complex. Similar but larger vesicles were seen in the cytoplasm and also near the plasma membrane. Occasional dense bodies, probably lysosomes, were seen. Type B cells (Fig. 9) were characterized by abundant RER. Golgi complexes were seen but were less prominent than in type A cells. These cells had fewer mitochondria and less smooth walled vesicles than type A cells. Micropinocytotic vesicles were occasionally seen. The intermediate cells were few in number. These cells had features in common with both cell types, namely prominent Golgi complexes, well developed RER both micropinocytotic vesicles and smooth walled vesicles and mitochondria.

\section{Joints with synovitis caused by intraarticular fracture}

In this group the relative number of type A cells was moderately increased. A frequently encountered feature was an elongation of both type A and B cells. These cells had their long axis 
LIGHT AND ELECTRON MICROSCOPIC INVESTIGATION OF EQUINE SYNOVIAL MEMBRANE

A COMPARISON BETWEEN HEALTHY JOINTS AND JOINTS WITH INTRAARTICULAR FRACTURES AND OSTEOCHONDROSIS DISSECANS 
Figure 1. Photomicrograph of a $1 \mu$ section of synovial membrane from healthy joint. The synovial membrane is of areolar type. The lining cells are loosely arranged parallel to the membrane surface. Two mast cells (Mc), a few plasma cells (Pc), a macrophage (Ma) and a blood vessel (BV) are seen in the subintimal layer of loose connective tissue. Toluidine blue, $550 \times$.

F i g u r e 2. Photomicrograph of $1 \mu$ section of same specimen as in Fig. 1. A tendency towards elongation of the lining cells is seen. In immediate contact with the lining layer there is a capillary (Ca) with two erythrocytes. Toluidine blue, $1,400 \times$.

F i g u r e 3. Photomicrograph of $1 \mu$ section of fibrous synovial membrane from joint with synovitis caused by intraarticular fracture. The figure shows an area of normal appearing synovial membrane. A single layer of fibrocyte-like synovial cells lines the membrane surface. Toluidine blue, $600 \times$.

F i g u r e 4. Photomicrograph of synovial membrane from joint with synovitis caused by intraarticular fracture. Hyperplasia, elongation and shaggy appearance of the synovial lining cells are demonstrated. An area with degenerate and necrotic lining cells is seen (arrows). $\mathrm{H} \& \mathrm{E}, 140 \times$.

F i g u r e 5. Photomicrograph of synovial membrane from joint with synovitis caused by osteochondrosis dissecans. Edematous villi with synovial lining cell proliferation and aggregates of mononuclear inflammatory cells around blood vessels are demonstrated. $\mathrm{H} \& \mathrm{E}, 110 \times$.

Figure 6. Photomicrograph of $1 \mu$ section of synovial membrane from joint with synovitis caused by osteochondrosis dissecans. Shaggy appearance of synovial lining layer due to hyperplasia, elongation, vacuolization and detachment of synovial lining cells is shown. Subintimal layer of areolar type contains macrophages (Ma) with phagocytized material and inflammatory cells (plasma cells and lymphocytes). Toluidine blue, $360 \times$.

F i g u r e 7. Detail of Fig. 6. Elongation, vacuolization and detachment of synovial lining cells is demonstrated. Toluidine blue, 1,300 $\times$.

F i g u r e 8. Electronmicrograph of synovial layer from healthy joint. The cells are of B type and lie loosely arranged parallel to the membrane surface. The intercellular space (IS) contains an electron lucent flocculent material and is in direct continuity with the joint space (JS, arrow). B cells are rich in rough endoplasmic reticulum (*). Lead citrate, $4,500 \times$. 

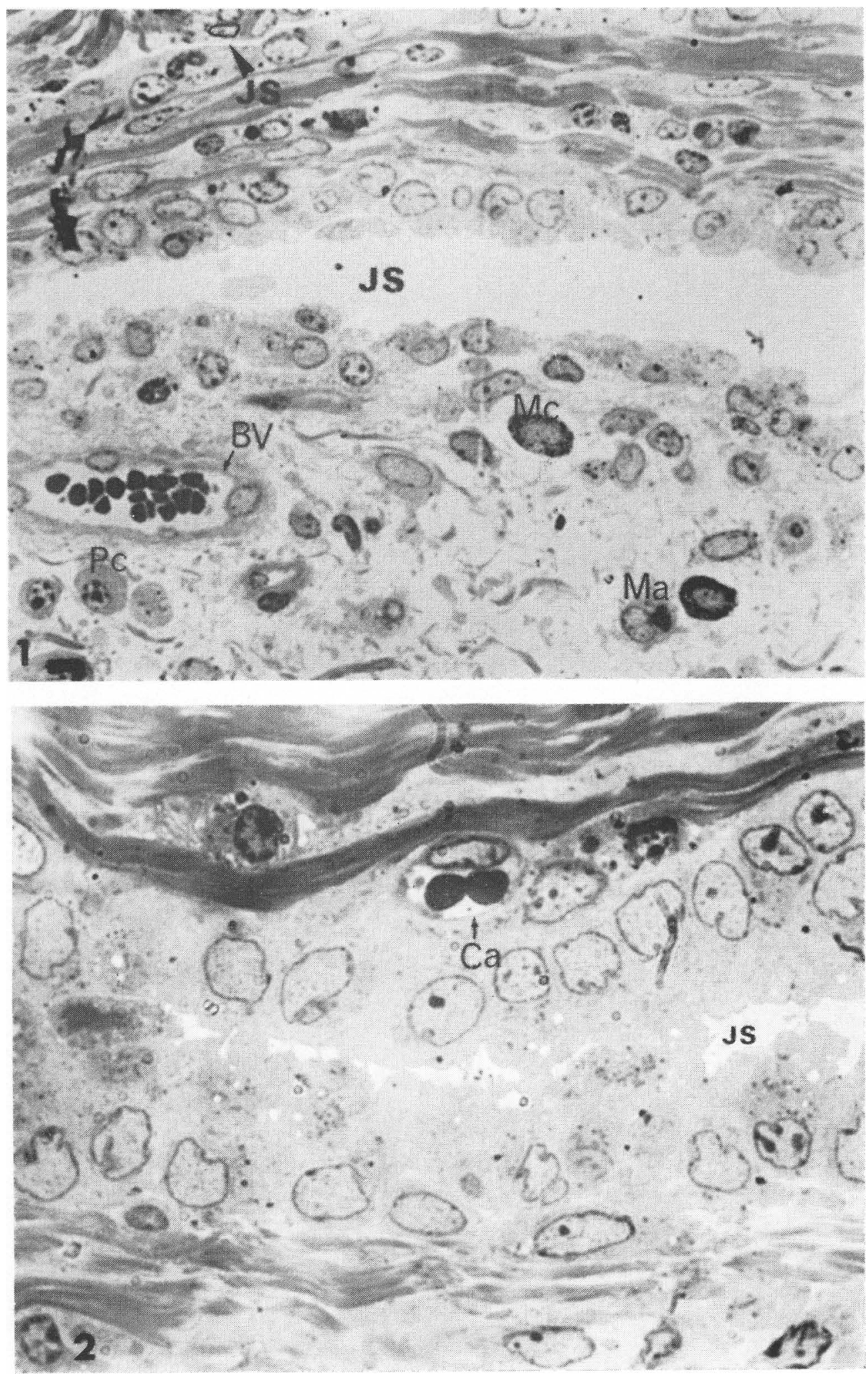


\section{JS}

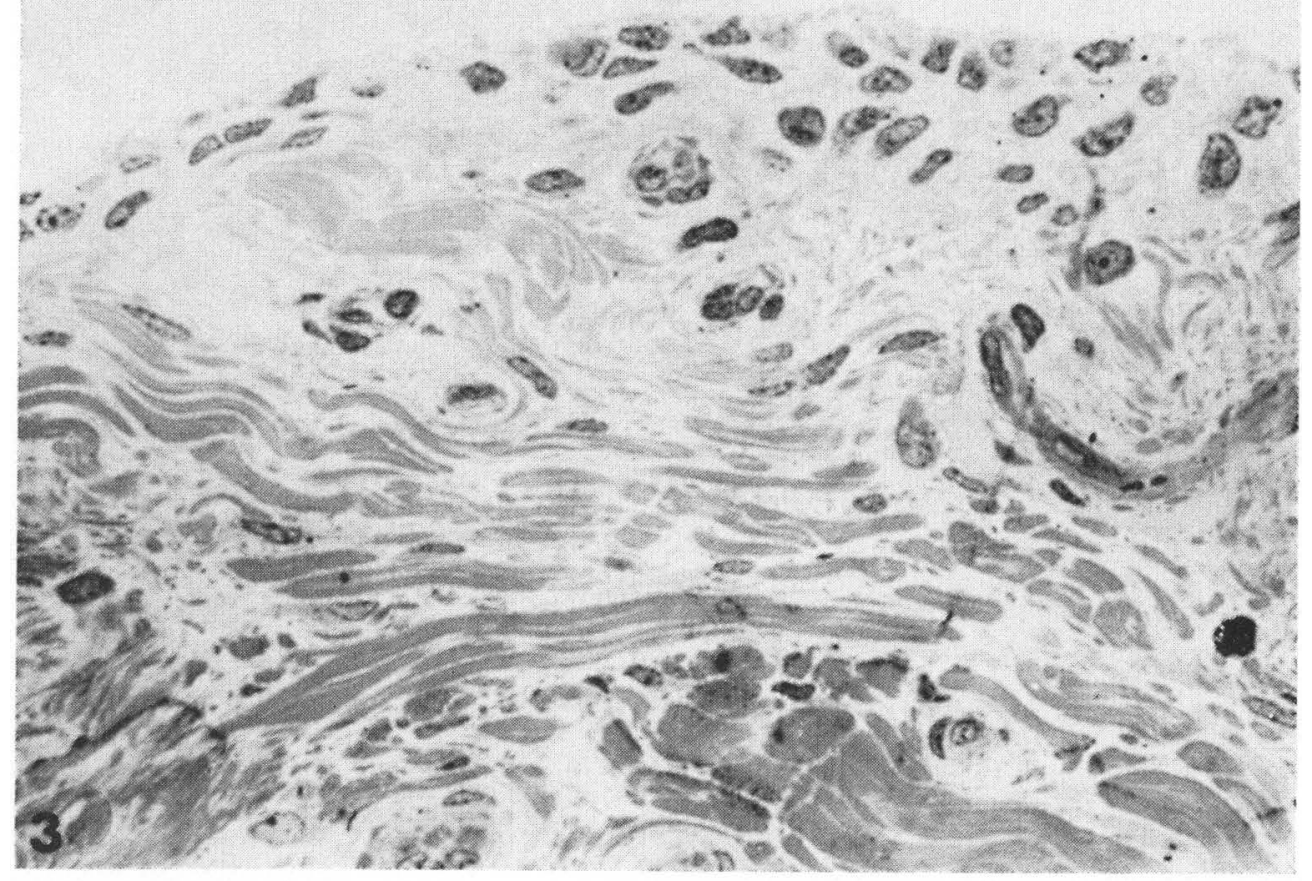

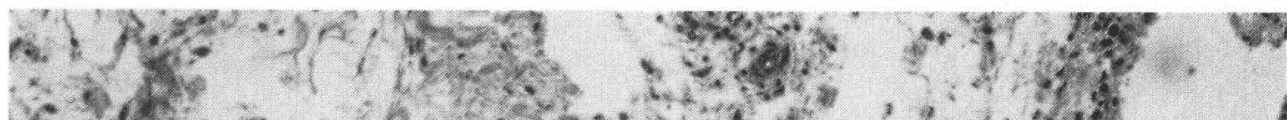

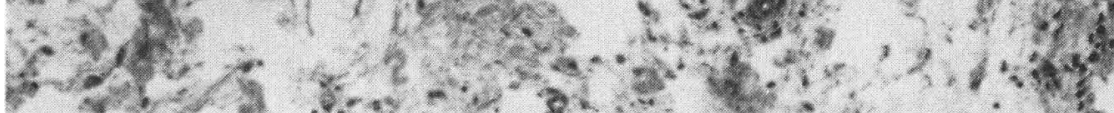

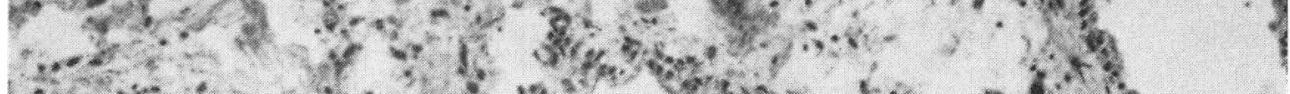

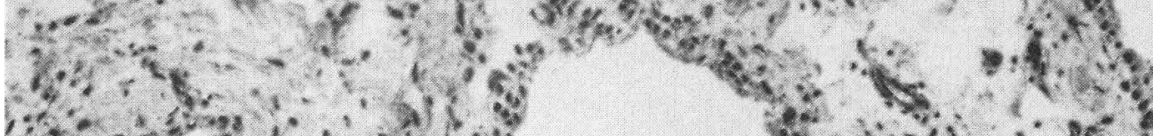

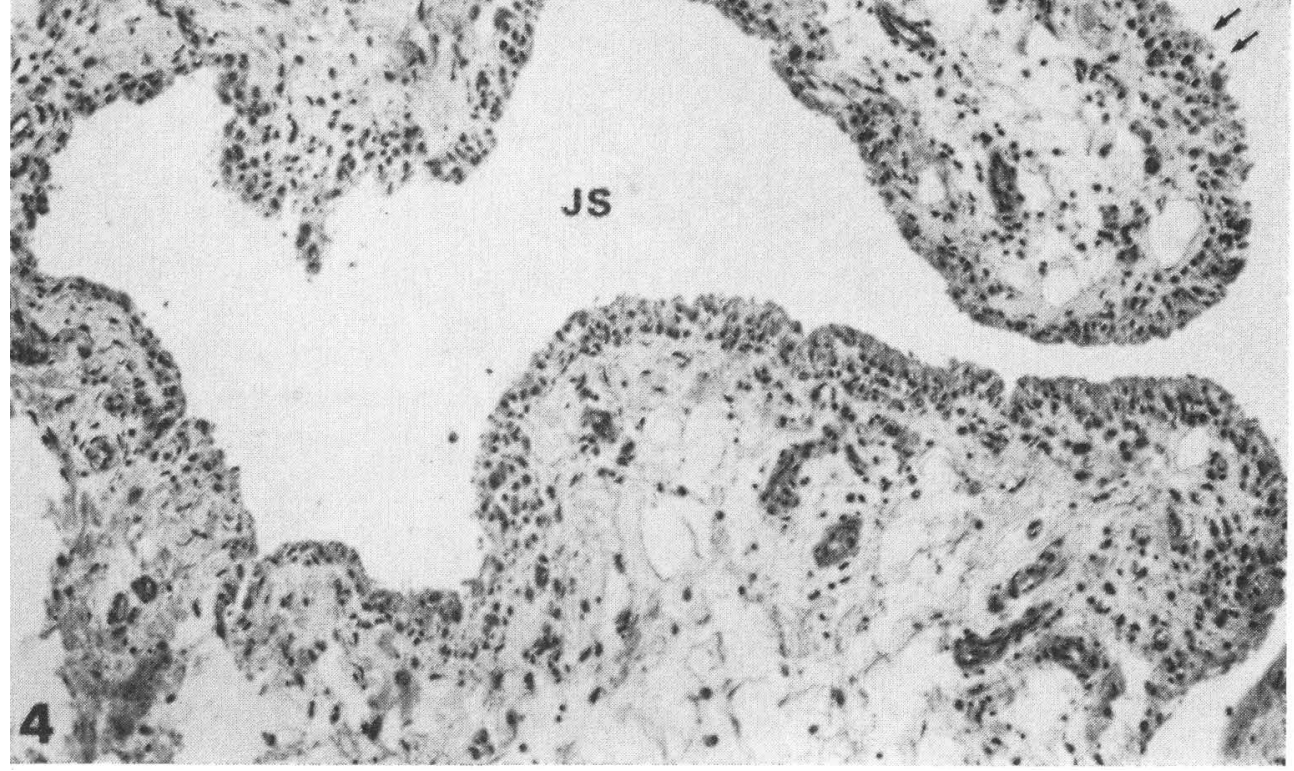




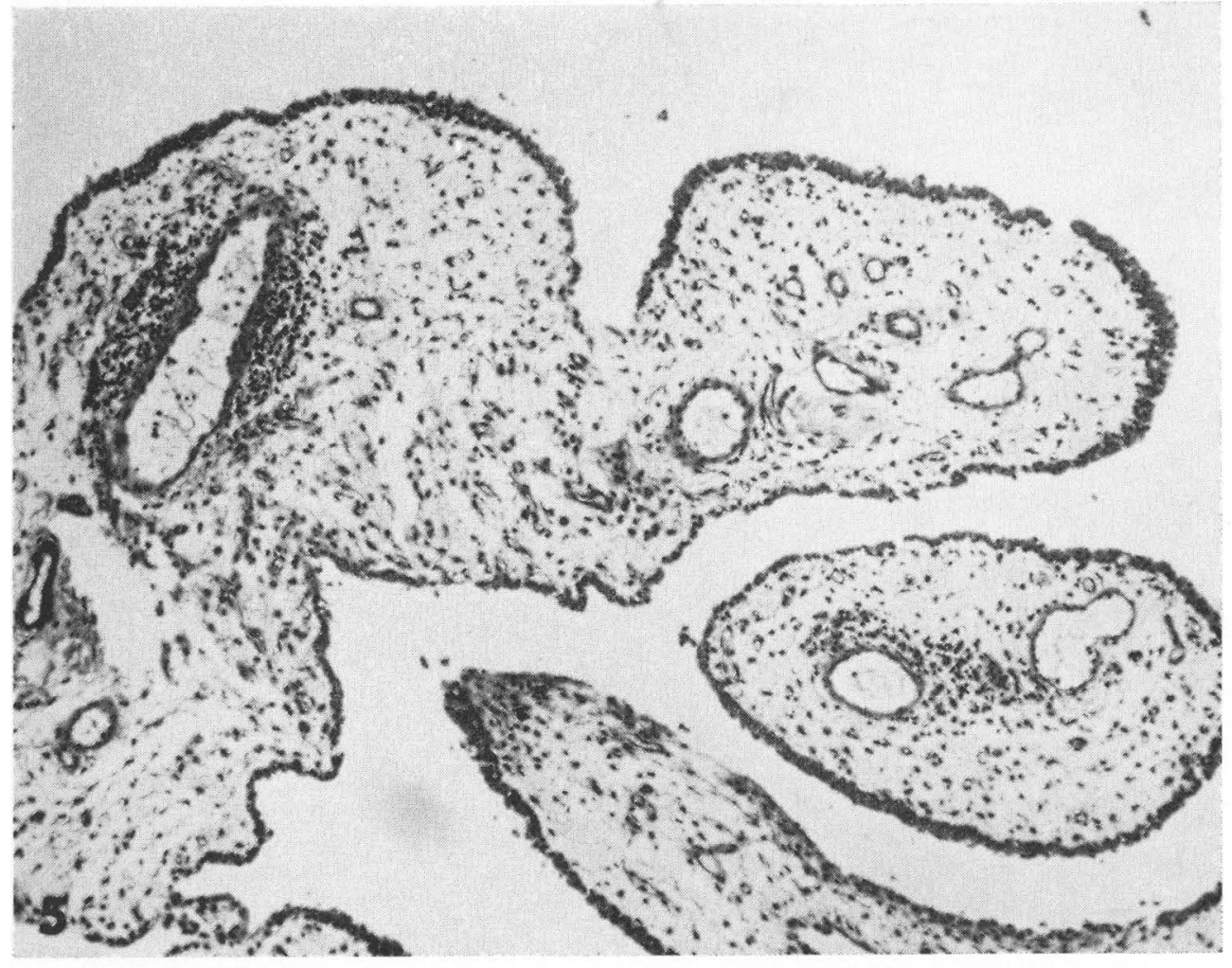

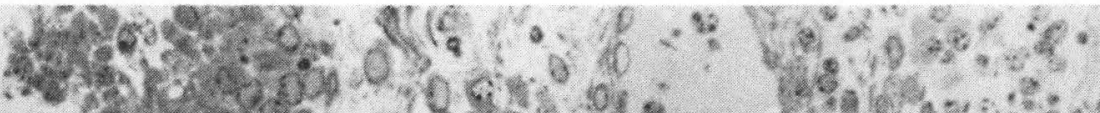

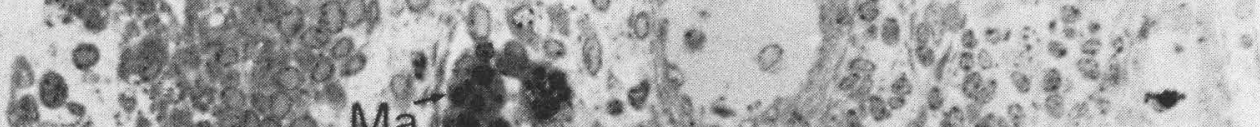

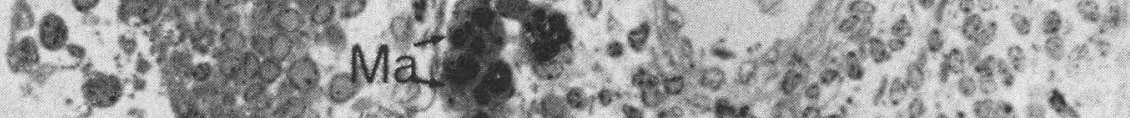

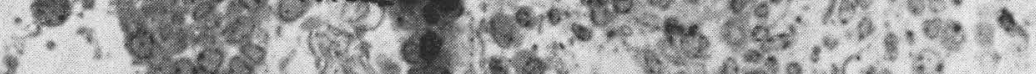

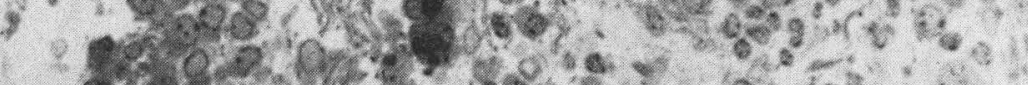

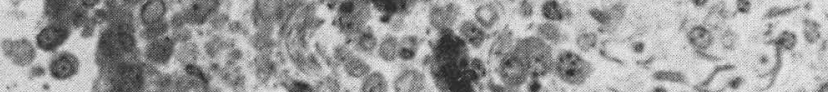

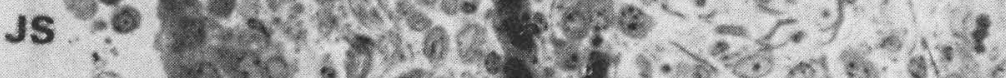

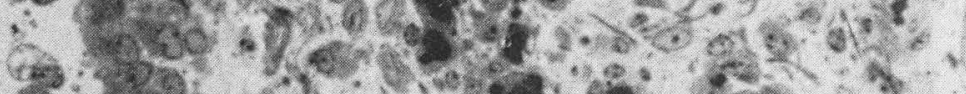

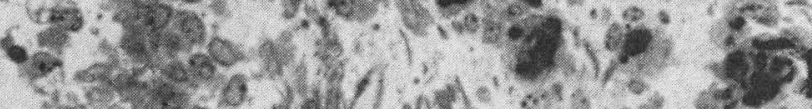

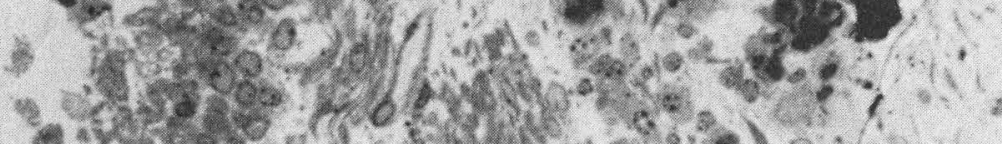

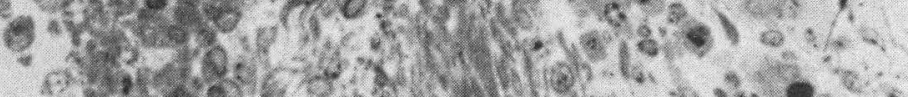

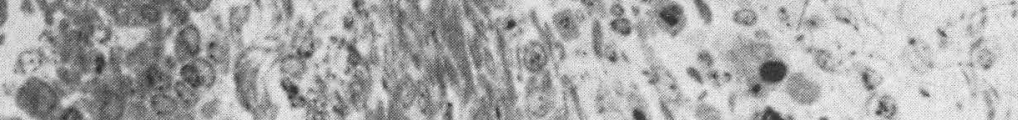

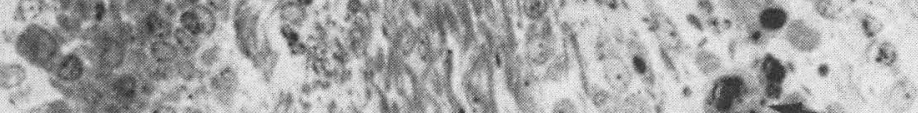

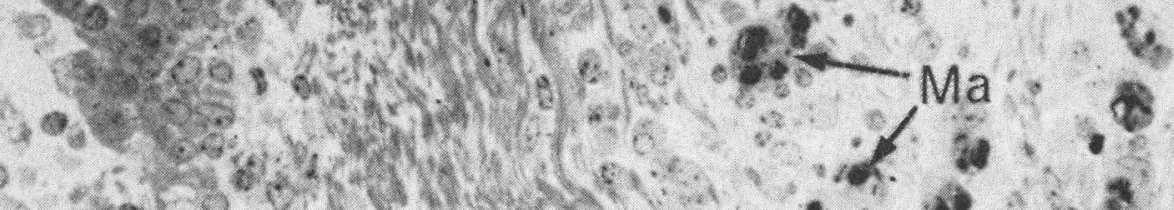

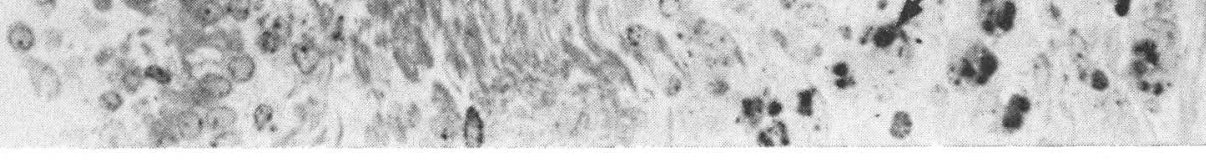




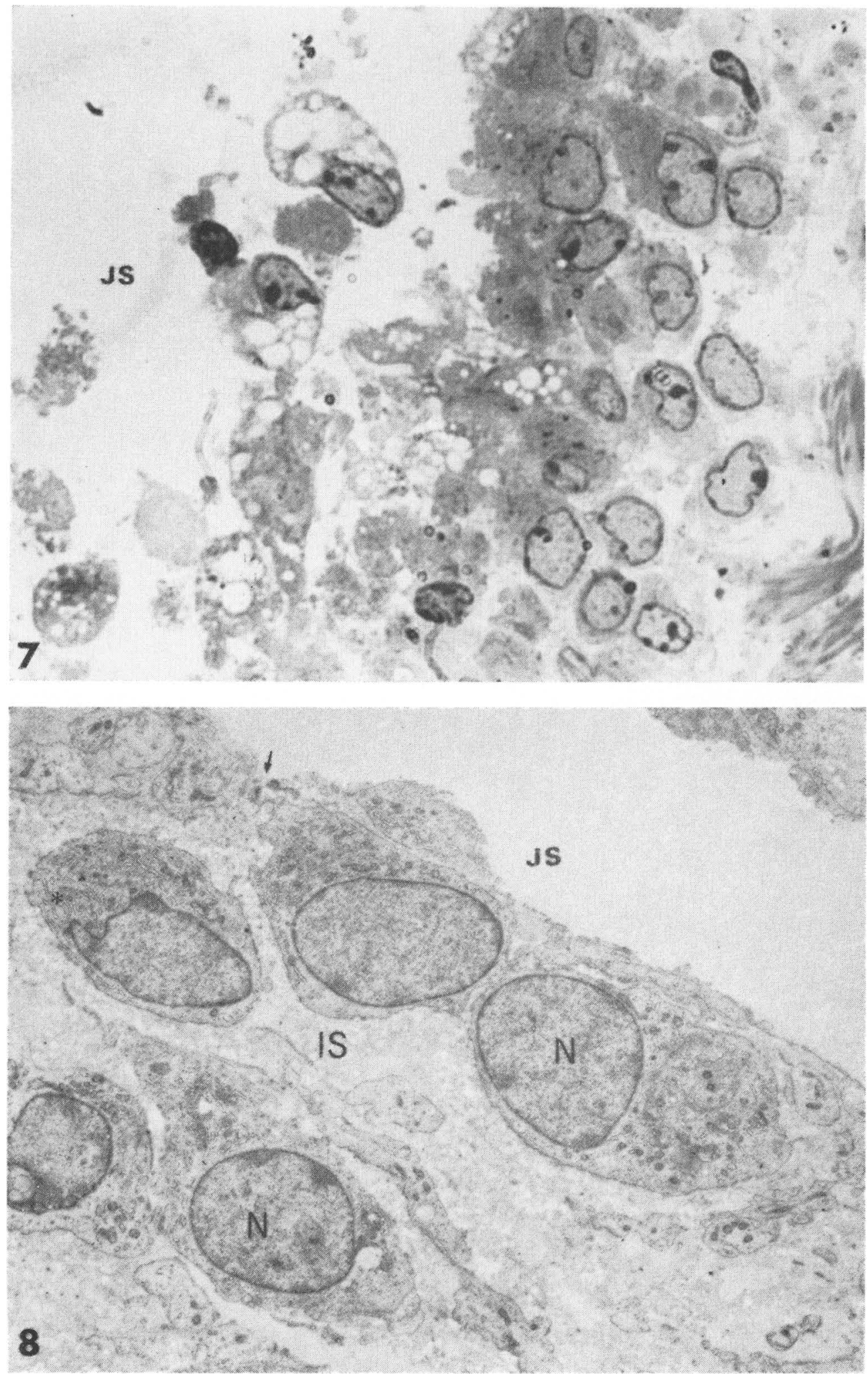




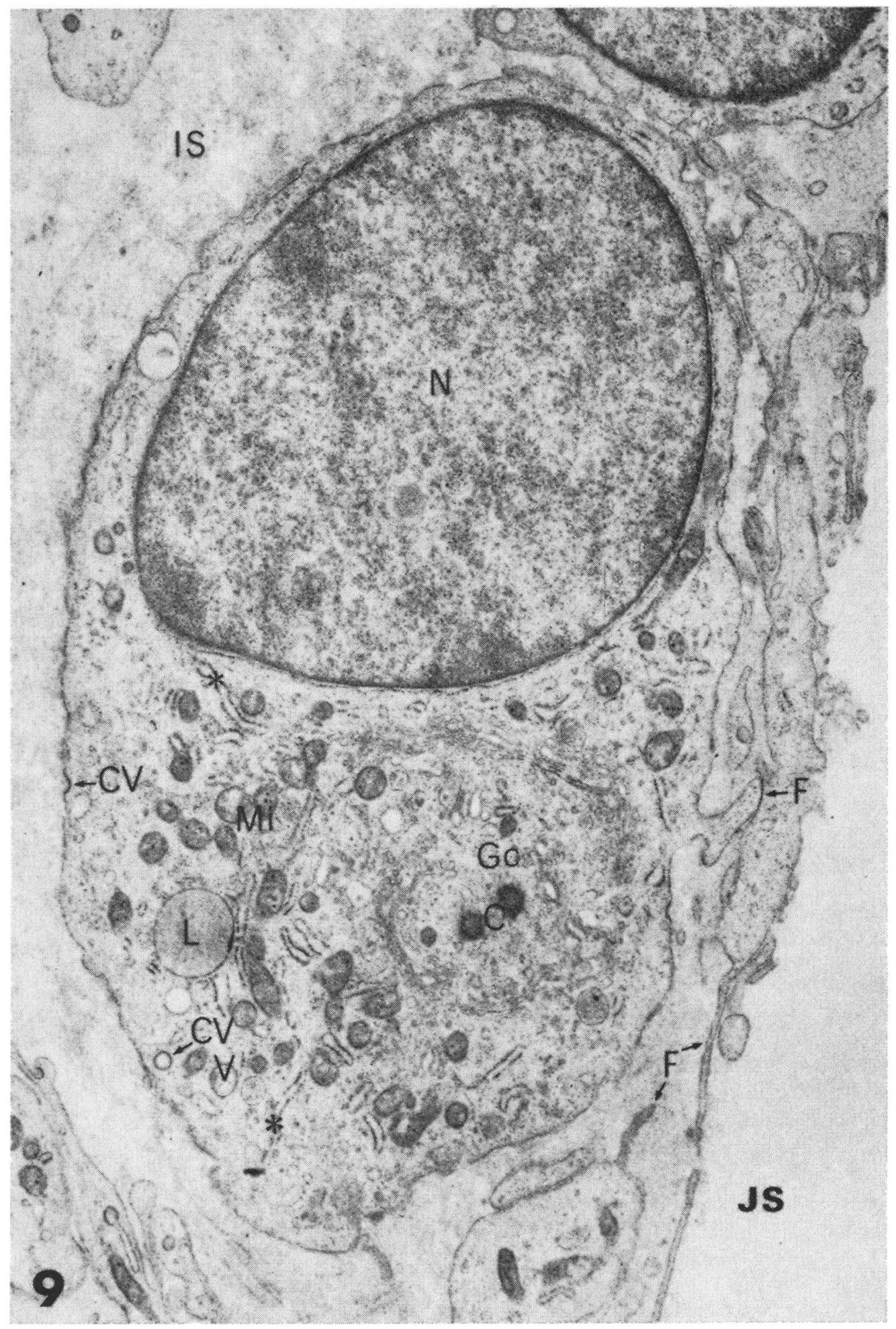




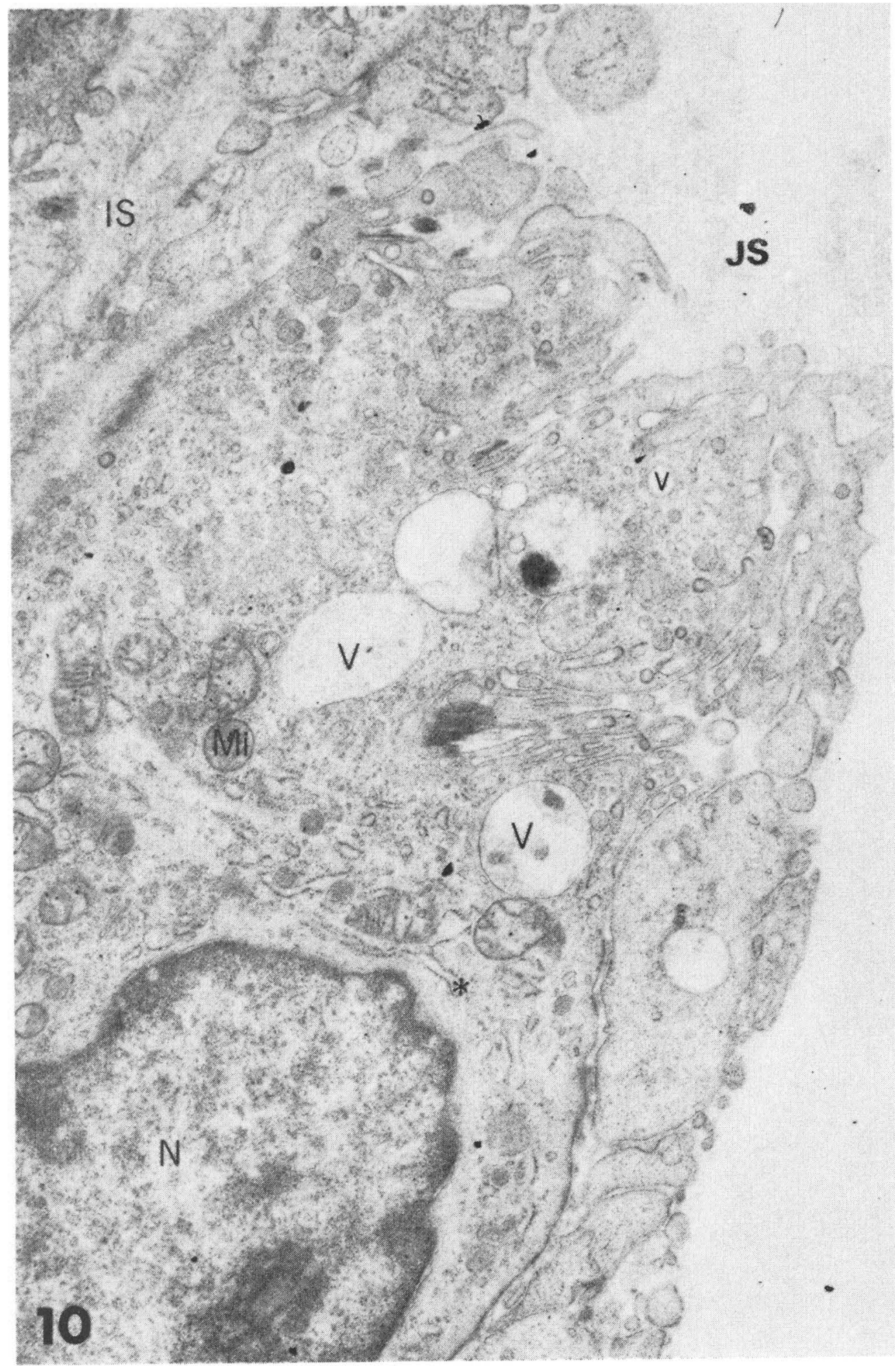




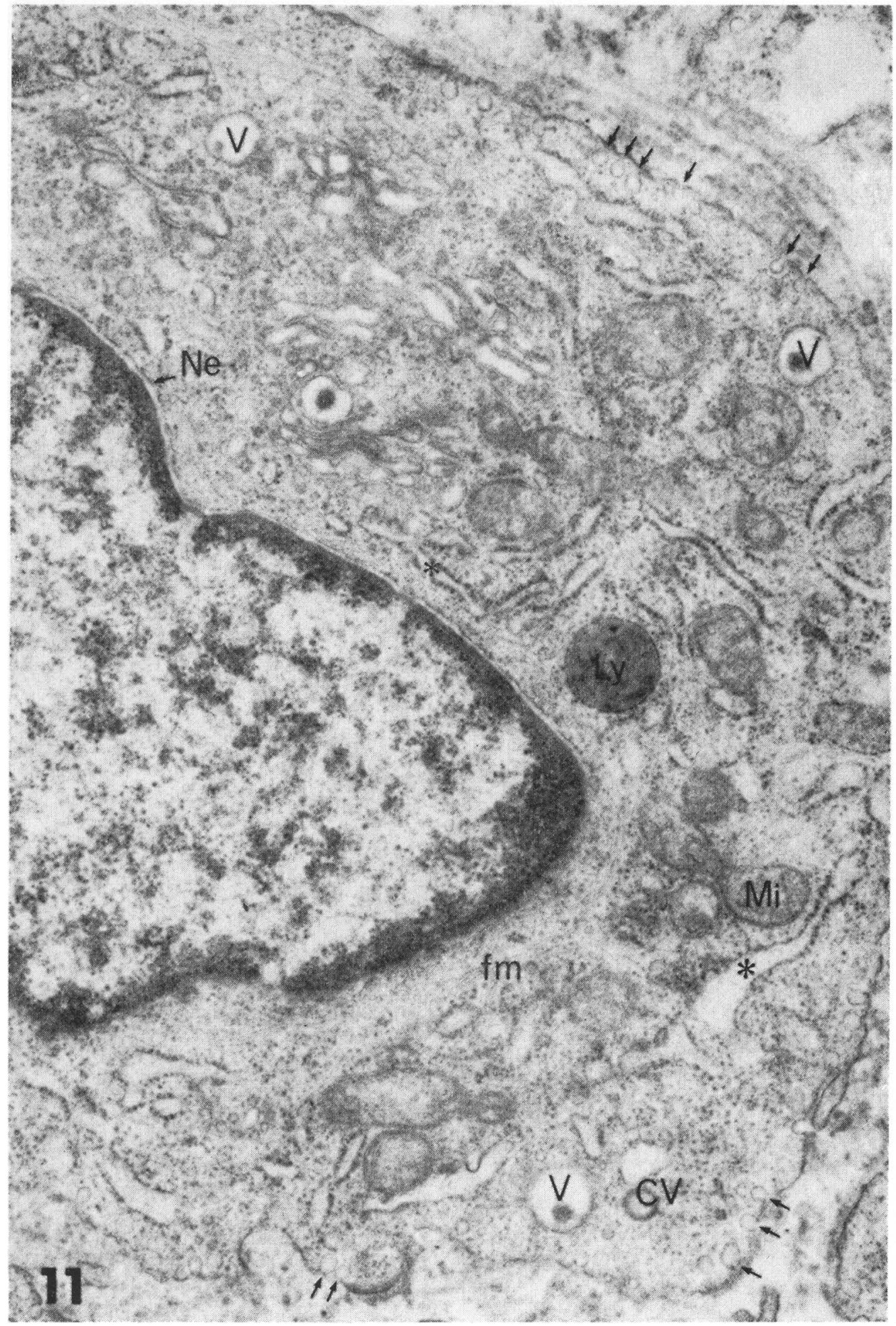




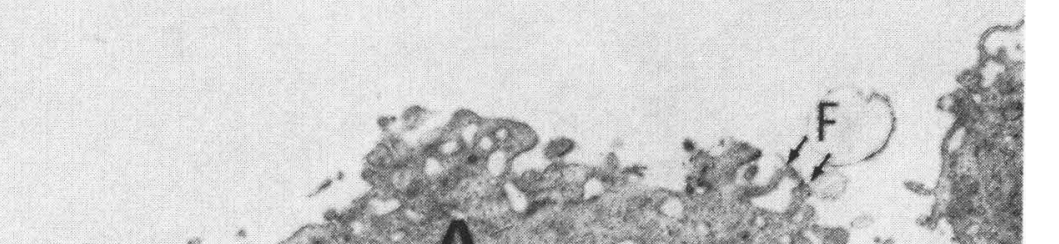

JS

3.

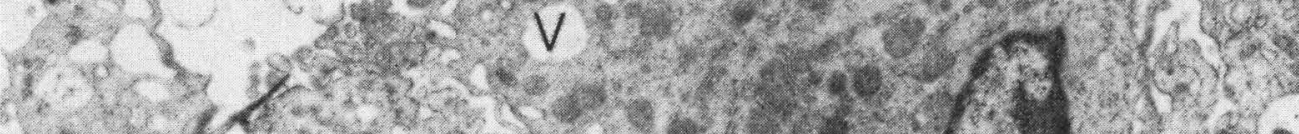

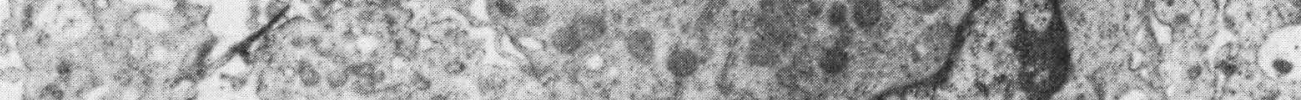

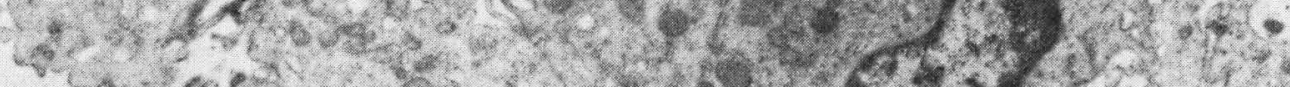

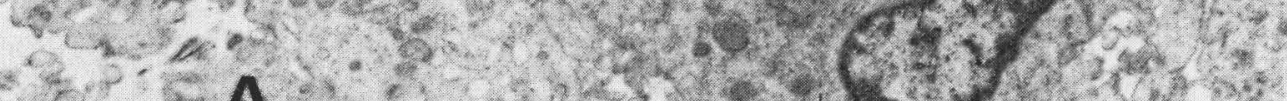

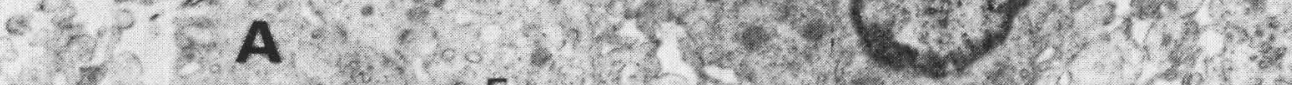

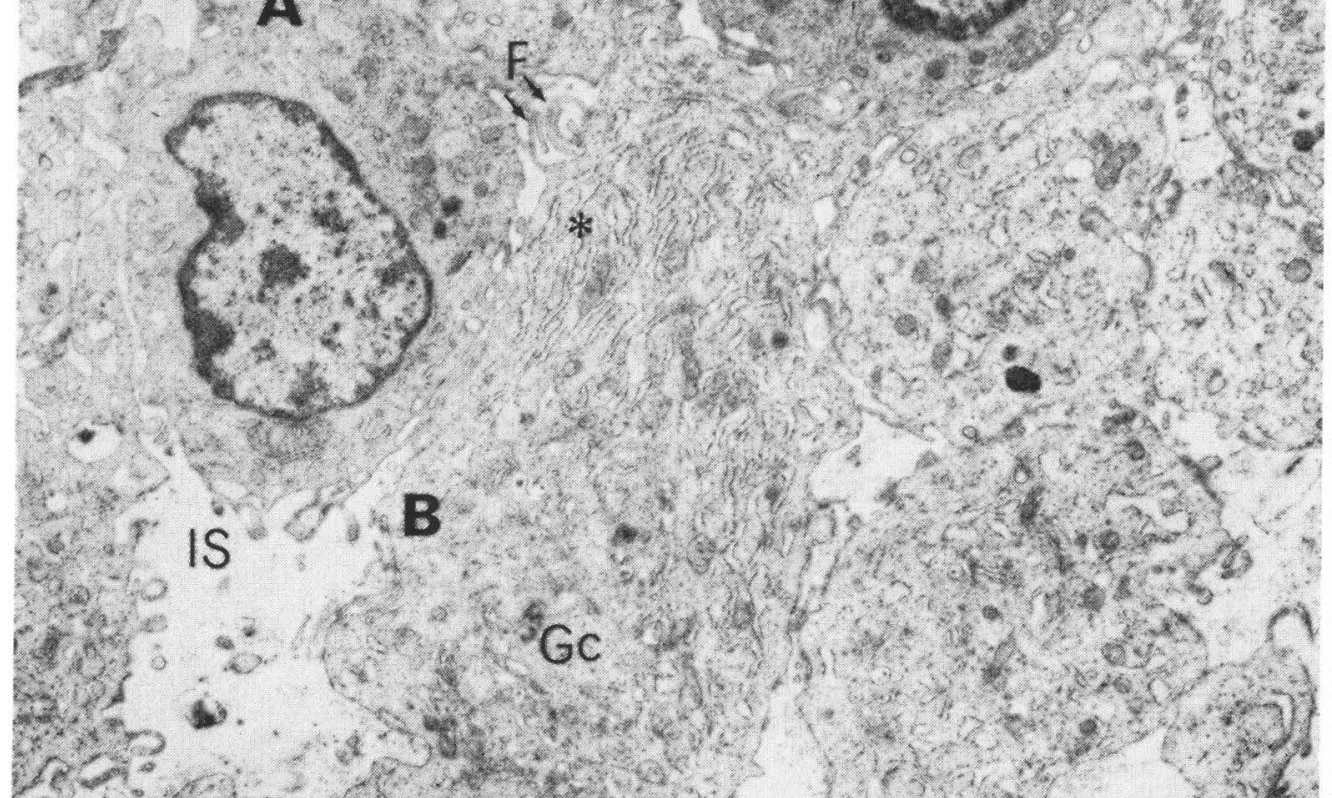

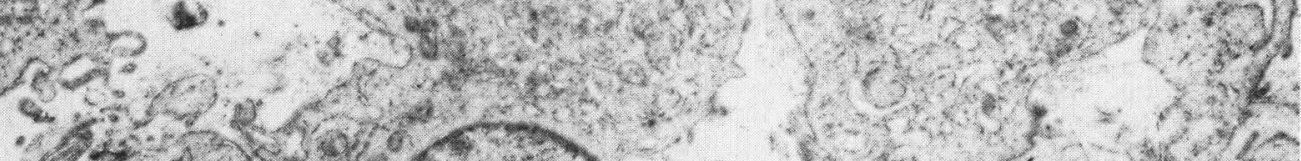

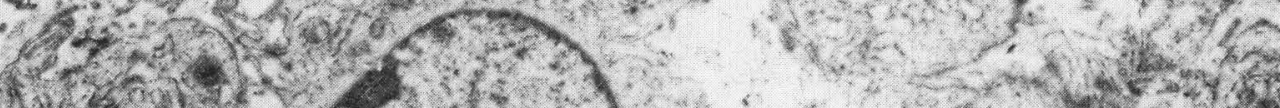
2.

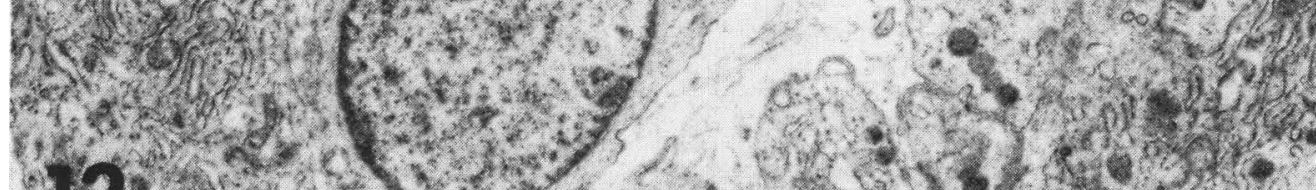
12. $2.12,35, \ldots$ 


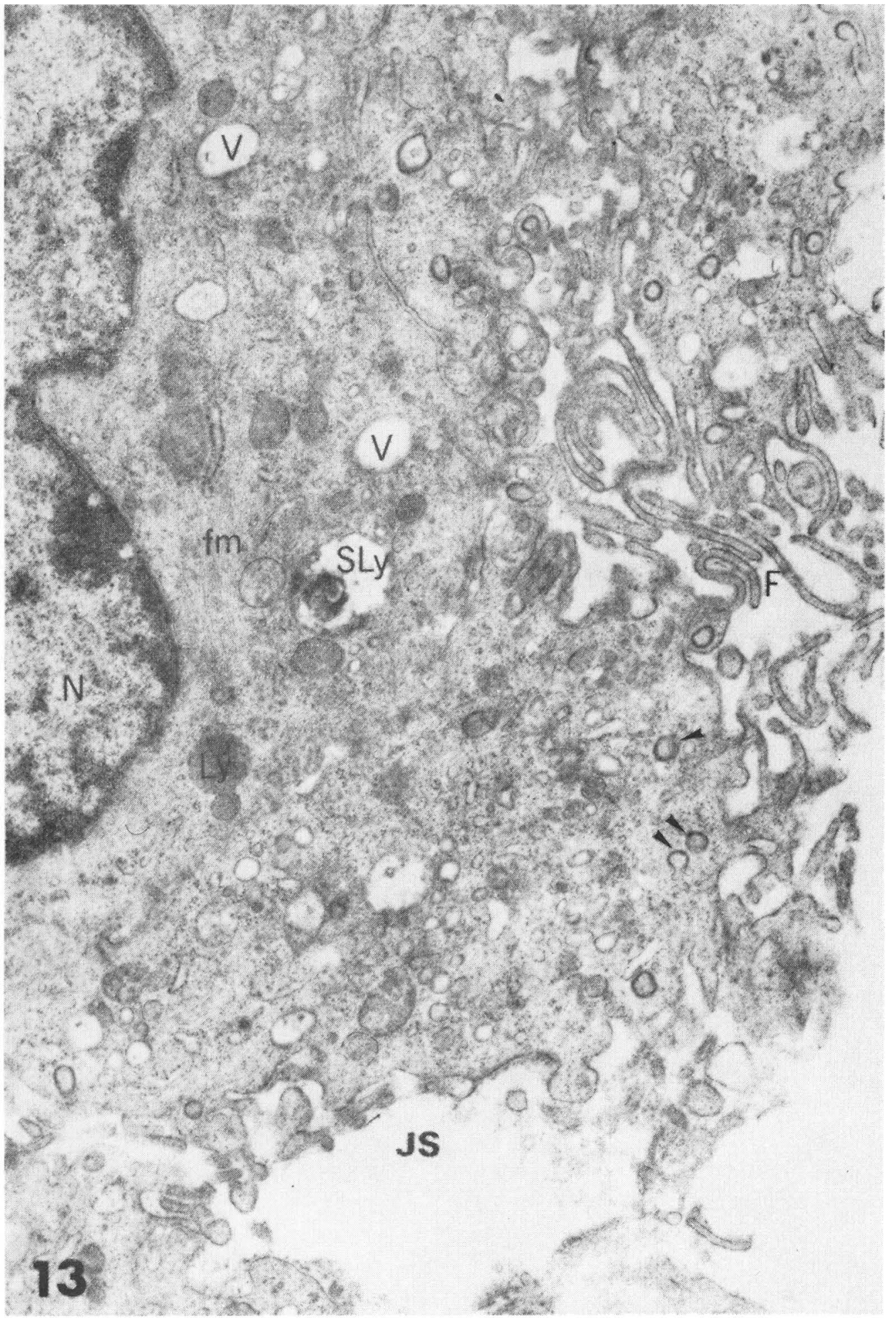



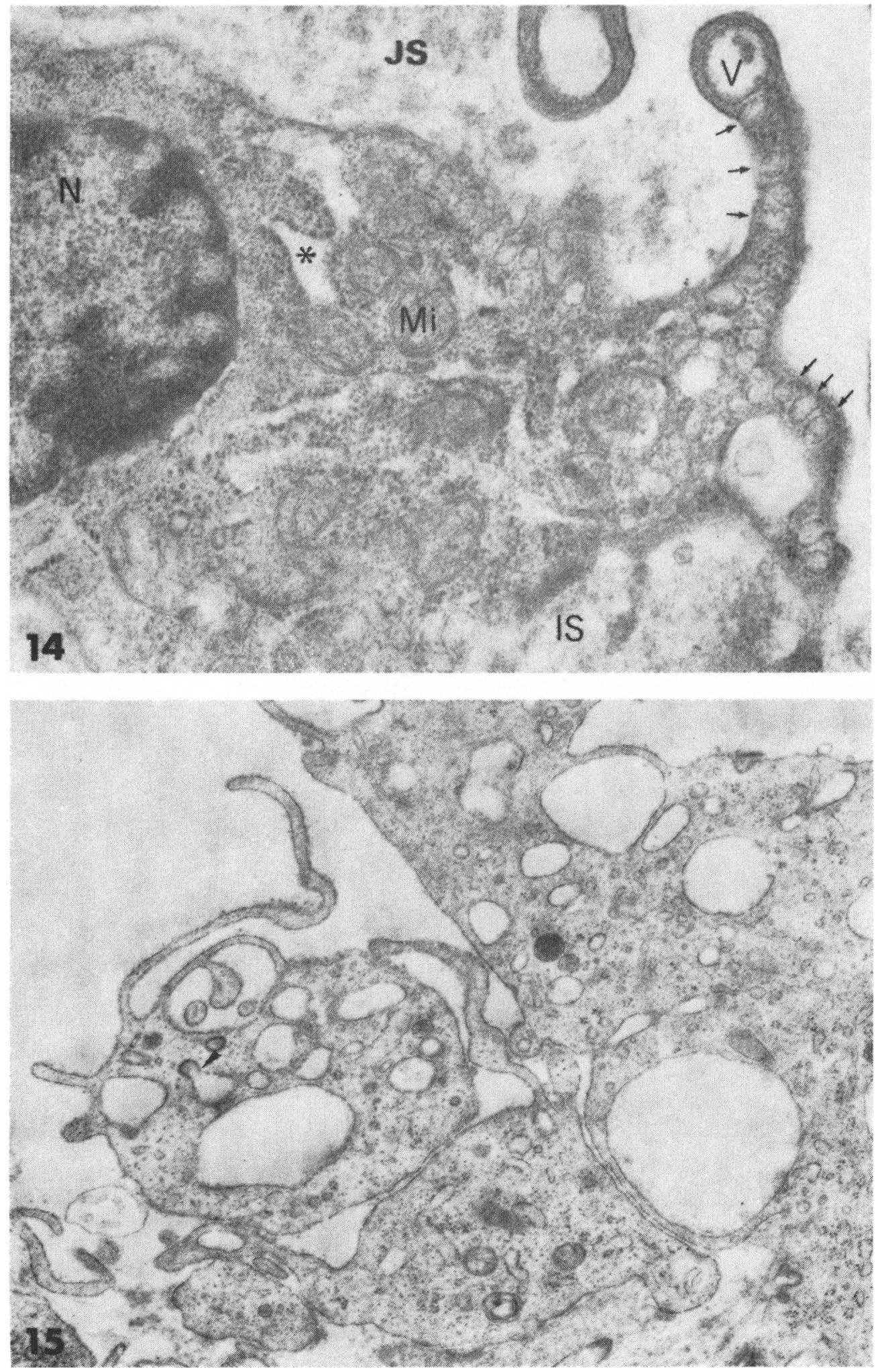

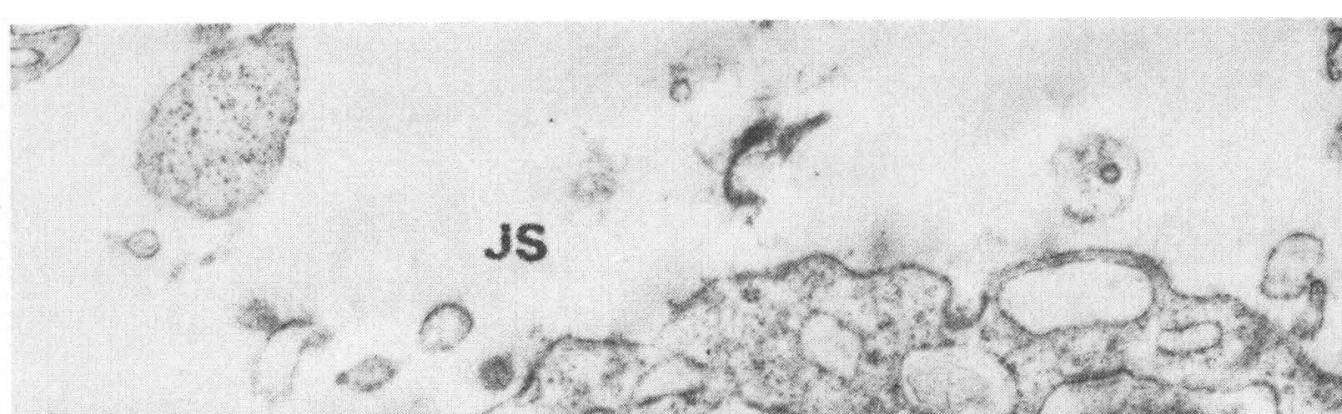

40

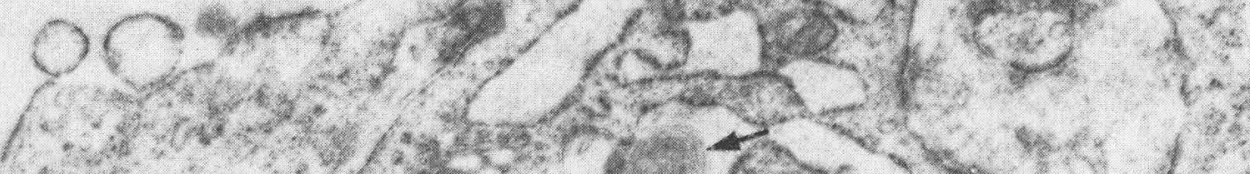

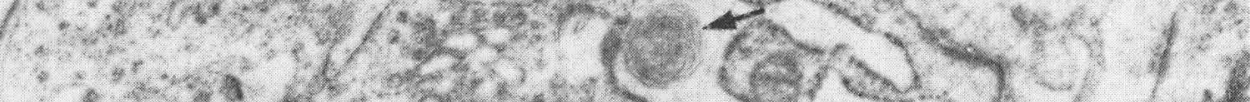

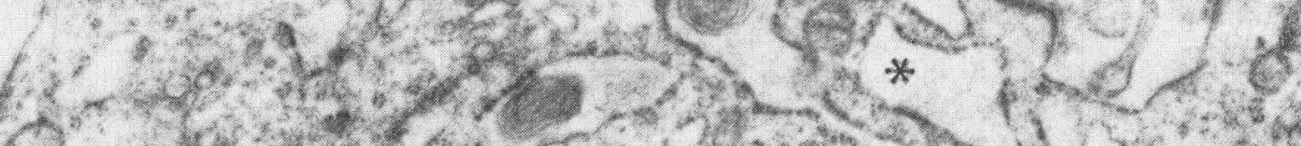

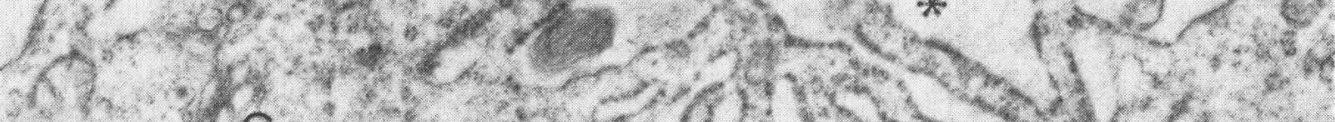

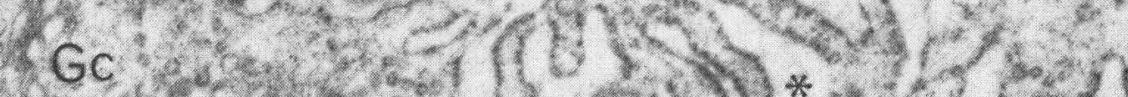

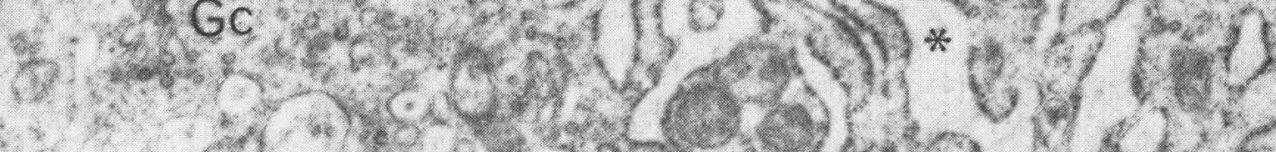

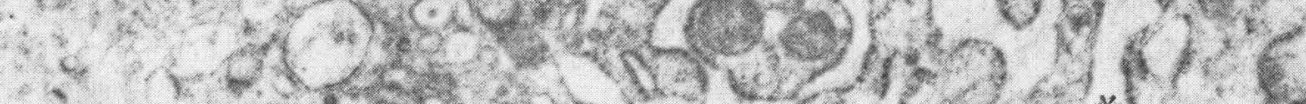

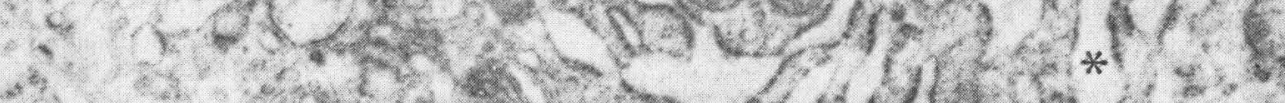

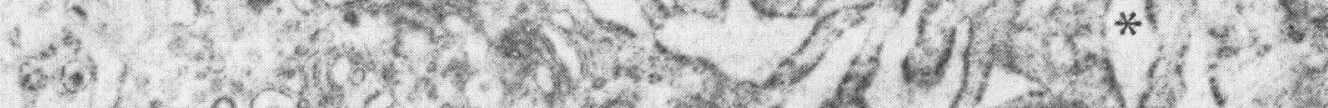

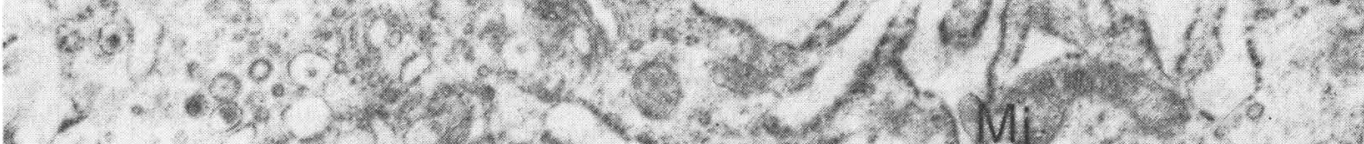

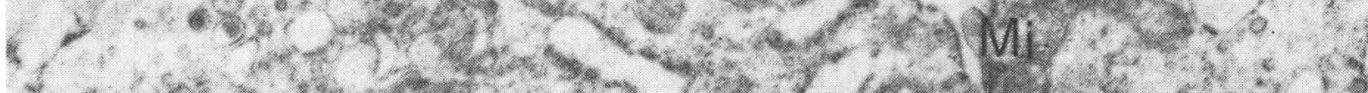

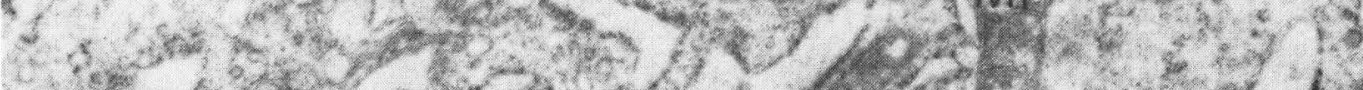

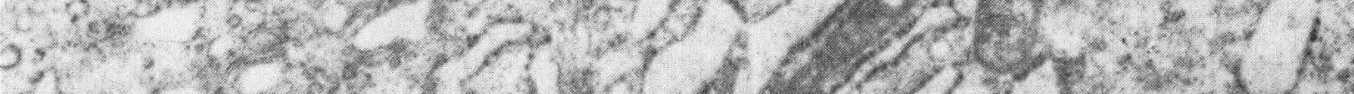

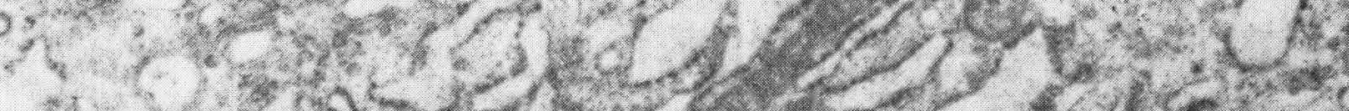

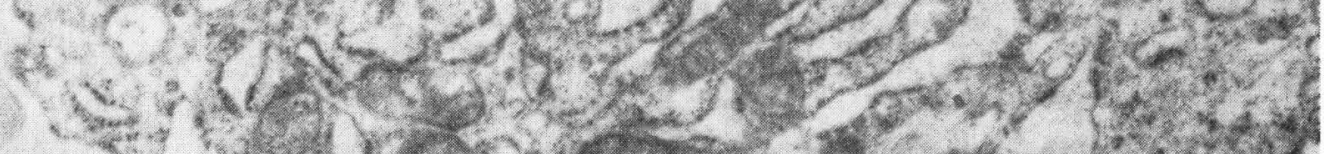

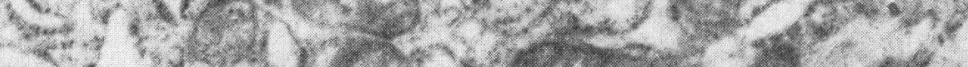

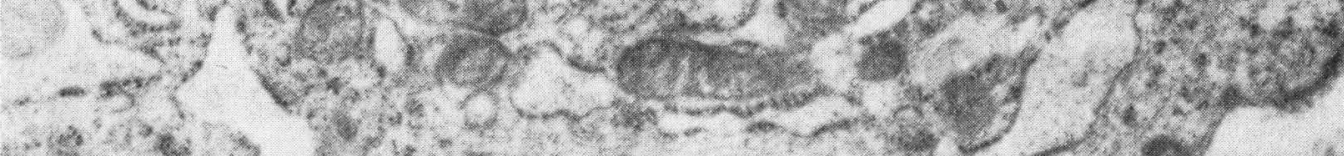

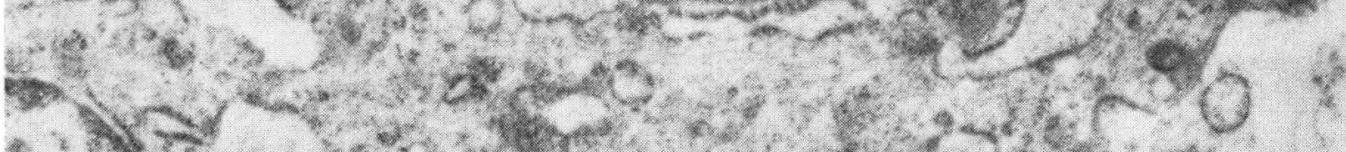

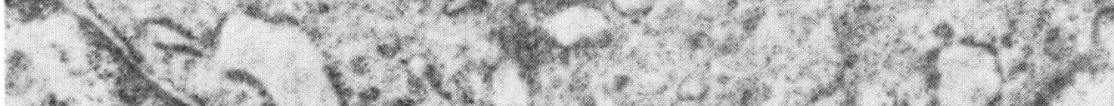
1.5.

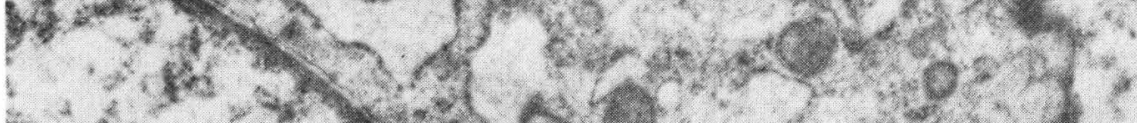
;.

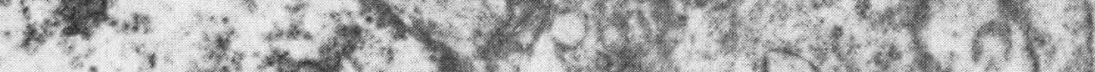
$16-2)=0$ $c_{\infty}$ it 


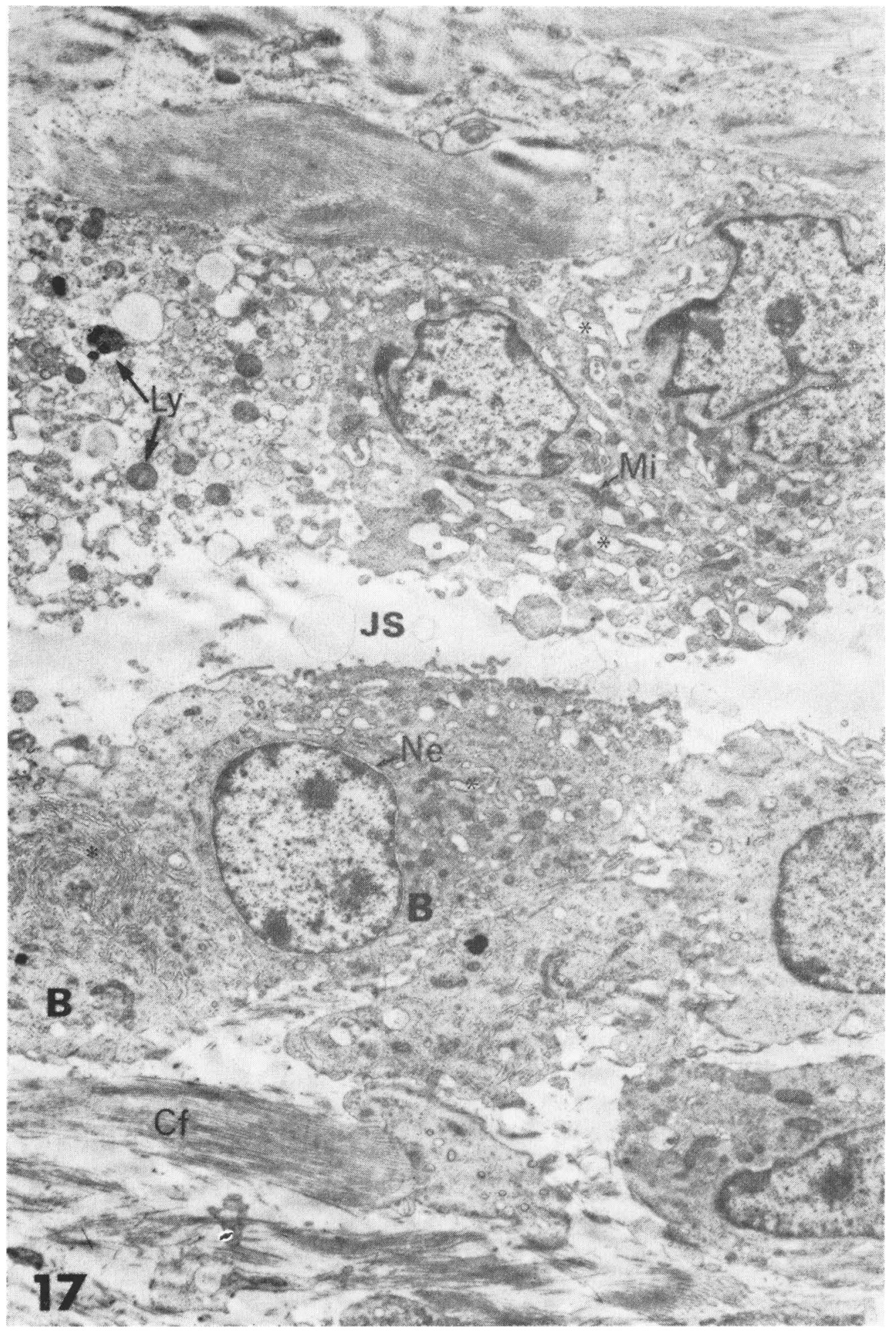


Figure 9. Electronmicrograph of synovial membrane from healthy joint. Detail of Fig. 8. B cells in general possess a well developed rough endoplasmic reticulum, but have fewer mitochondria and vesicles and a less developed Golgi complex than type A cells. The cell shown in this figure was classified as a type B cell. There is a well developed rough endoplasmic reticulum (*), a prominent Golgi complex (Gc) with two centrioles (C), many mitochondria (Mi) and a few smooth-walled vesicles (V) and coated vesicles (CV). A few blunt filopodia project towards the joint space (JS). Lead citrate, 14,000 $\times$.

F i g u r e 10. Electronmicrograph of synovial membrane from healthy joint. Part of a synovial lining cell of A type is demonstrated. The cell has many mitochondria (Mi), but the rough endoplasmic reticulum (*) is sparse. The part of the cell lacing the joint space (JS) is rich in filopodia. This part of the cell contains many membrane bound small vesicles (v). Some large vesicles (V) contain electron dense and flocculent material probably of lysosome origin. Lead citrate, $12,000 \times$.

Figure 11. Electronmicrograph of synovial lining layer showing detail of an intermediate type cell from joint with synovitis caused by intraarticular fracture. Intermediate type cells have features in common with both A and B cells. A prominent Golgi complex is situated near the nucleus. The cell is rich in rough endoplasmic reticulum (*) which at places is slightly dilated. Many micropinocytotic vesicles (arrows) are seen in contact with the plasma membrane. There are also many mitochondria (Mi), free ribosomes, a few vesicles (V) with electron-dense material - both in the Golgi complex and at the periphery of the cell. A dense body, probably a lysosome (Ly), is seen. Filamentous material $(\mathrm{fm})$ is present in the perinuclear region. Uranyl acetate, $30,000 \times$.

Figure 12 . Electronmicrograph of synovial lining layer of joint with synovitis caused by intraarticular fracture. A type B cell (B) with an accentuated elongation is seen. The nucleus is at the pole of the cell furthest from the joint space. This cell has abundant rough endoplasmic reticulum (*) which is slightly dilated. The Golgi complex (Gc) is prominent. Two A cells (A) are situated at the synovial membrane surface. One of the A cells is slightly elongated. The cytoplasm of the A cells is more electron-dense than that of the B cell. The A cells have little rough endoplasmic reticulum but are rich in mitochondria and smooth-walled vesicles (V). Both the B and A cells have many filopodia (F). Uranyl acetate, 6,000 $\times$. 
F i g u r e 13 . Electronmicrograph of synovial lining layer showing detail of an A cell from joint with synovitis caused by intraarticular fracture. The cell surface next to the joint space (JS) is enlarged through many filopodia (F). Abundant filamentous material ( $\mathrm{fm}$ ) is located next to the nucleus (N). Numerous smooth-walled vesicles (V) and coated vesicles (arrows) are situated in the periphery of the cell. A dense body - probably a lysosome (Ly) and a large vesicle containing electron-dense material - probably a secondary lysosome $($ SLy) are seen. Uranyl acetate, 25,000 $\times$.

Figur e 14 . Electronmicrograph of synovial cell from joint with synovitis caused by osteochondrosis dissecans. Detail of an A cell with projections towards the joint space (JS). The projections are rich in micropinocytotic vesicles (arrows). A large membrane bound vesicle (V) with electron-dense material is seen at the tip of one projection. The cisternae of the rough endoplasmic reticulum (*) are distended and the ribosomes are partly lost. Many mitochondria (Mi) are seen. The intercellular substance (IS) contains electron-dense flocculent material. Lead citrate, $40,000 \times$.

F i g u r 15. Electronmicrograph of synovial membrane from joint with synovitis caused by osteochondrosis dissecans, showing detail of the cell surface of a lining cell. Many long and delicate filopodia are seen. Small and large membrane-bound vesicles are frequent. Fusion of such a vesicle and a coated vesicle is seen (arrow). Lead citrate, $18,000 \times$.

F ig u r e 16 . Electronmicrograph of synovial lining cell from joint with synovitis caused by osteochondrosis dissecans. Detail of a B cell. The cell has a well developed rough endoplasmic reticulum $(*)$ the cisternae of which are dilated and contain some whirled bodies (arrow). Golgi complex (Gc) is rich in vesicles of varying sizes, some containing slight electron-dense material. Lead citrate, 18,000 $\times$.

Figure 17. Electronmicrograph of synovial membrane from joint with synovitis caused by osteochondrosis dissecans. The synovial membrane from two opposing villi is seen. Two B cells (B) are seen (bottom). One of the cells has a prominent rough endoplasmic reticulum $(*)$. The rough endoplasmic reticulum $(*)$ of the other cell is moderately dilated. This cell also has a slightly dilated nuclear envelope $(\mathrm{Ne})$. In the other villus two cells with highly dilated rough endoplasnitic reticulum $(*)$ are seen (top right). These cells are probably B cells. Their nuclei are lobulated. Part of a totally disintegrated cell is shown (top left). Free organelles, vesicles and dense bodies, probably lysosomes (Ly), are seen, without a detectable plasma membrane. Lead citrate, $5,000 \times$. 
perpendicular to the membrane surface, the nucleus being located at the pole furthest from the joint space while the cytoplasm was directed towards the joint space (Fig. 12). Both cell types had increased numbers of filopodia projecting from the cell surface. The number of filopodia was more markedly increased in type B cells and the filopodia were long and slender. The projections of the type A cells were shorter and less delicate. The cell projections were mainly directed towards the joint space. The number of coated vesicles were few in both cell types but apparently were more numerous than in the controls (Fig. 13).

Type B cells often had an increased RER which was usually arranged in parallel arrays. The Golgi complexes were more prominent in the type B cells in this group than in healthy joints. These observations were made predominantly in elongated cells (Fig. 12). Micropinocytotic vesicles occurred in B cells in approximately the same frequency as in the controls.

The A cells had an increased number of smooth-walled vesicles of varying size. The peripheral vesicles usually were smaller than those more centrally positioned. Many invaginations on the plasma membranes indicated that the smooth-walled vesicles were formed through pinocytosis. The A cells had increased numbers of dense bodies, probably lysosomes. Some of the larger smooth-walled vesicles contained a varying amount of electron dense material. The perinuclear region was more rich in microfilaments than in control joints.

Intermediate type of cells were infrequent but showed in general the same alterations as seen in type A and B cells (Fig. 11).

Joints with synovitis caused by osteochondrosis dissecans

In this group cells with the same alterations as described in the previous group and cells with more advanced changes were seen. There was an increase in the relative number of type A cells.

The RER of the B cells showed a varying dilatation of the cisternae. In moderate dilatation the parallel nature of the membranes was preserved. Highly dilated cisternae were transformed into vesicles. The vesiculation was combined with a loss of ribosomes (Fig. 15). The content of the dilated cisternae was mainly electron lucent but some slightly electron dense flocculent mate- 
rial as well as infrequent whirled bodies were seen (Fig. 16). Cellular projections were of the same character as described previously but the filopodia were more numerous and were longer. In B cells and intermediate cells the number of micropinocytotic vesicles was increased (Fig. 14).

Coated vesicles were frequently seen in both $A$ and $B$ cells. In the A cells the number of smooth-walled vesicles was increased. Dense bodies and smooth-walled vesicles with electron dense material, probably lysosomes and secondary lysosomes respectively were also more frequent.

The mitochondria showed varying alterations. Most frequently they were condensed. In other instances they were enlarged having an electron lucent matrix. In both cases irregularities and loss of the cristal and membranous configurations were seen. The plasma membranes frequently were discontinuous. The nuclei were often lobulated and indented and the nuclear envelopes had varying degrees of dilatation.

It was not possible to classify cells with the most advanced alterations as type A or type B cells. They were dominated by the presence of numerous vesicles, vacuoles and dense bodies of undefined origins, often without plasma membrane or with a discontinuous one (Fig. 17).

\section{DISCUSSION}

The light microscopic examination showed that the equine synovial membrane is principally of the same character as that of other species. Thus areolar, fibrous and adipose synovial membrane was found in the joints which were investigated. The areolar type was most frequently encountered. The synovial membrane consisted of intimal and subintimal layers. The varying characters of the synovial membrane reflect the physiologic function of the joint. Consequently the fibrous synovial membrane is more common in joints with low range of motility, e. g. pastern joint and near the insertion of the joint capsule. Areolar and adipose synovial membrane dominate in highly motile joints, e. g. fetlock joint (i. a. Nilsson \& Olsson 1973).

The intimal layer was found to consist of two types of cells, I and II. Type I cells had abundant cytoplasm and were found in areolar and adipose synovial membranes. Type II cells which were spindle-shaped, resembling fibrocytes, were found in fibrous synovial tissue. Sufficient histological evidence to enable 
a further differentiation of the synovial lining cells was not obtained.

To achieve good conformity with respect to the kind of disease, severity of symptoms and joints involved, synovial membrane specimens were taken from joints with intraarticular fractures within two weeks after the trauma, and from joints with osteochondrosis dissecans more than three months after the onset of symptoms.

The same type of changes were observed in both groups of diseased joints although differences were noted between the two groups. These differences were regarded as differences in degree rather than in character. This is in accordance with what could be expected, since in cases of synovitis caused by intraarticular fracture the clinical symptoms were of recent onset, less than two weeks, while osteochondrotic synovitis was of three months' or longer duration.

The changes were characteristic of inflammation, namely edema, increased vascularization, infiltration of inflammatory cells, increased numbers of synovial lining cells and hypertrophy of villi. Phagocytized erythrocytes in lining cells and hemosiderosis indicated recent hemorrhage and the phagocytic potential of synovial lining cells. The technique with Eponembedded $1 \mu$ thick sections for histological examination had not previously been used in similar investigations in the horse. This technique provides a better preservation with less artefacts than paraffin embedding, and thus gives improved detail of the structures examined.

Ultrastructurally two distinct types of lining cells were observed in both healthy and diseased joints. The characteristics of $A$ and $B$ cells are in accordance with what has been reported in other species (i. a. Ghadially \& Roy 1969). Hence it seems relevant to apply the same nomenclature for the equine synovial lining cells i. e. type A and type $B$ cells. The type A cells were characterized by frequent smooth-walled vesicles but sparse rough endoplasmic reticulum. The type $B$ cells contained abundant rough endoplasmic reticulum but few smooth-walled vesicles. Golgi complexes were seen in both cell types. Ghadially $\&$ Roy reported that type A cells were more numerous than type $B$ cells in healthy joints in man, rabbit and rat. In the present investigation the opposite observation was made in the horse. 
On the basis of ultrastructural characteristics of the synovial lining cells some fundamental facts concerning their function can be predicted. The type $B$ cell with a prominent rough endoplasmic reticulum and Golgi complex is likely to produce protein. The type A cell containing many smooth-walled vesicles, lysosomes in different stages and Golgi complex, is likely to exert phagocytosis. Some investigators have emphasized the ultrastructural character of the cells by designating them as F- and M-cells, thus indicating the fibrocyte-like and the macrophage-like appearance of the type $B$ and the type $A$ cells respectively (i. a. Watanabe et al. 1974 and Hirohata \& Morimoto 1971).

Studies by Roy \& Ghadially (1967) have shown that the type A cells are responsible for hyaluronic acid production. This statement was based on the colloidal iron staining technique which is specific for acid mucopolysaccharides. According to the same authors the type $B$ cell is responsible for synthesis of export protein.

In the present investigation some intermediate cells, i. e. cells sharing features with both type $A$ and $B$ cells, were seen. According to some authors the synovial lining cells should not be regarded as different cell entities but rather as different functional stages of cells (i. a. Ghadially \& Roy).

Synovial membrane specimens from joints with intraarticular fractures were obtained within two weeks after the trauma. Thus the alterations seen in this group were considered to be early changes. The elongated synovial lining cells in this group were orientated with their cytoplasm towards the joint space. It is likely that this alteration is an expression of a functional orientation of the cell.

An enlargement of the cell surface caused by increased numbers and size of filopodia was seen in both cell types in the diseased joints. This probably enables enhanced pinocytosis and micropinocytosis. Increased numbers of micropinocytotic vesicles were also observed in the filopodia of lining cells from joints with synovitis.

The present investigation showed that the rough endoplasmic reticulum underwent gradual changes. Initially an increase in the number of rough endoplasmic reticulum cisternae was seen. In the later stages a gradual dilatation was observed. The dilatation progressed to a stage where the cisternae formed large vacuoles. 
Rough endoplasmic reticulum hyperplasia and a light dilatation of the cisternae most likely reflect an increased activity. Vesiculation on the other hand is a phenomenon seen in degenerating cells (Ghadially 1975) and is thought to be an expression of altered osmosis through an increased water permeability. Thus one can speculate that to a certain degree the dilatation is an expression of an increased activity, but beyond a certain point it reflects regressive changes.

Dilatation and vesiculation of the rough endoplasmic reticulum is known to be accompanied by mitochondrial swelling (Ghadially). In the present investigation mitochondrial alterations were observed in connection with the more advanced rough endoplasmic reticulum changes and consisted of either mitochondrial condensation or mitochondrial swelling with disturbance of the membranous and cristal configurations. The mitochondrial swelling can be explained by altered osmosis (Ghadially).

Type A cells showed increasing numbers of lysosomes and smooth-walled vesicles with advancing degree of synovitis. Some of the smooth-walled vesicles contained electron dense material indicating that they were secondary lysosomes. Judging from their content it is most likely that these secondary lysosomes were phagolysosomes, and one can assume that such alterations are expressions of increased phagocytic activity.

Cells with advanced cytoplasmic changes also showed accompanying nuclear changes. The nuclei frequently were indented and the nuclear envelope showed a varying degree of dilatation. These changes were regarded as an expression of degeneration.

The duration of synovitis caused by intraarticular fracture was short - less than two weeks - and the inflammation of synovial membrane was mild to moderate. The cellular changes were hyperplasia and elongation of cells, increase in cell organelles i. e. rough endoplasmic reticulum, Golgi complexes, vesicles and lysomes. This was thought to be indicative of increased cellular activity. In cases with synovitis caused by osteochondrosis dissecans the duration of the disease was long more than three months - and the inflammation was more severe than in the former group. The lining cells showed the same changes as in the afore mentioned group, but besides more advanced changes were seen. These were dilatation and vesi- 
culation of the rough endoplasmic reticulum, dilatation of the nuclear envelope, mitochondrial condensation and disappearance of the plasma membrane and cellular disintegration.

\section{REFERENCES}

Auböck, L., H. Fladerer \& G. Klein: Neue Ultrastrukturelle Befunde an der Synovialis bei progredient chronischer Polyarthritis. (New ultrastructural findings in the synovial membrane in rheumatoid arthritis). Z. Rheumatol. 1974, 33, 87-106.

Ball, J., J. A. Chapman \& K. D. Muirden: The uptake of iron in rabbit synovial tissue following intraarticular injection of iron dextran. J. Cell Biol. 1964, 22, 351-364.

Barland, P., A. B. Novikoff \& D. Hamerman: Electron microscopy of the human synovial membrane. J. Cell Biol. 1962, 14, 207220.

Barland, P., A. B. Novikoff \& D. Hamerman: Fine structure and cytochemistry of the rheumatoid synovial membrane, with special reference to lysosomes. Amer. J. Path. 1964, 44, 853-859.

Barnett, C. H., D. V. Davies \& M. A. MacConnaill: Synovial Joints. Their Structure and Mechanics. Longman, Green \& Co., Ltd., London 1961, p. 23-34.

Bauer, W., M. V. Ropes \& H. Waine: The physiology of articular structures. Physiol. Rev. 1940, 20, $272-312$.

Bhawan, J., H. Tandon \& S. Roy: Ultrastructure of synovial membrane in pyogenic arthritis. Arch. Path. 1973, 96, 155-160.

Bierther, M. F. W. \& W. Streit: Elektronmikroskopische Untersuchungen an der Kniegelenksynovialis bei chronischer Polyarthritis. (Electronmicroscopical investigations on synovial membrane of the knee joint in rheumatoid arthritis). Z. Rheumaforsch. 1971, 30, 330-341.

Brånemark, P. J., R. Ekholm \& J. Goldie: To the question of angiopathy in rheumatoid arthritis. Acta orthop. scand. 1969, 40, $153-175$.

Cherney, D.: Fine structure of the rabbit synovial membrane during an immunologically-induced arthritis treated with metylprednisolonacetate. J. submicrosc. Cytol. 1971, 3, 217-229.

Cutlip, R. C.: Ultrastructure of the synovial membrane of lambs affected with Chlamydial polyarthritis. Amer. J. vet. Res. 1974, $35,171-176$.

Cutlip, R. C. \& N. F. Cheville: Structure of synovial membrane of sheep. Amer. J. vet. Res. 1973, 34, 45-50.

Davies, D. V. \& A. J. Palfrey: Electron microscopy of normal synovial membrane. In Studies of the Anatomy and Function of Bone and Joints. F. G. Evans, ed. Springer-Verlag, Berlin-HeidelbergNew York 1966, p. 1-16.

Ghadially, F. N.: Ultrastructural Pathology of the Cell. A Text and Atlas of Physiological and Pathological Alterations in Cell Fine Structure. Butterworths \& Co. Ltd., London and Boston 1975. 
Ghadially, F. N. \& S. Roy: Ultrastructure of Synovial Joints in Health and Disease. Butterworths \& Co. Ltd., London 1969.

Hirohata, K. \& I. Kobayashi: Fine structures of the synovial tissues in rheumatoid arthritis. Kobe J. med. Sci. 1964, 10, 195-225.

Hirohata, K. \& K. Morimoto: Ultrastructure of bone and joint diseases. Excerpta Med. (Amst.) 1971.

Key, J. A.: The synovial membrane of joints and bursae. In Special Cytology. II. Paul B. Hoeber, ed., New York 1932, 2, 1055-1076.

Langer, E. \& F. Huth: Untersuchungen über den submikroskopischen Bau der Synovialmembran. (Investigations on the submicroscopical structures of synovial membrane). Z. Zellforsch. 1960, $51,545-549$.

Lever, J. D. \& E. H. R. Ford: Histological, histochemical and electron microscopic observations on synovial membrane. Anat. Rec. $1959,132,525-539$.

Muirden, K. D.: An electron microscope study of the uptake of ferritin by the synovial membrane. Arthr. and Rheum. 1963,6, 289.

Nilsson, G. \& S.-E. Olsson: Radiologic and patho-anatomic changes in the distal joints and the phalanges of the standardbred horise. Acta vet. scand. 1973, Suppl. 44, 1-57.

Nilsson, G. \& L. Persson: Changes in the synovial fluid of equine fetlock joints with lesions in the cartilage and joint capsule. Acta vet. scand. 1973, Suppl. 44, 97-107.

Norton, W. L. \& M. Ziff: Electron microscopic observation on the rheumatoid synovial membrane. Arthr. and Rheum. 1966, 9, $589-610$.

Parker, R. H. \& C. M. Pearson: A simplified synovial biopsy needle. Arthr. and Rheum. 1963, 6, 172-176.

Persson, L.: On the synovia in horses. Acta vet. scand. 1971, Suppl. 35.

Roberts, E. D. \& F. K. Ramsey: Electron microscopy of porcine synovial cell layer. J. comp. Path. 1969, 79, 41-45.

Roy, S. \& F. N. Ghadially: Synthesis of hyaluronic acid by synovial cells. J. Path. Bact. 1967, 93, 555-557.

Schumacher, H. R., Jr.: The synovitis of pseudogout: Electron microscopic observations. Arthr. and Rheum. 1968, 11, 426-435.

Schumacher, R. H. \& R. C. Kitridou: Synovitis of recent onset. A clinicopathologic study during the first months of disease. Arthr. and Rheum. 1972, 15, 465-485.

Strömberg, B. \& S. Rejnö: Osteochondrosis in the horse. I. A clinical and radiological investigation. Acta radiol. (Stockh.) 1976. In press.

Watanabe, H., M. A. Spycher \& J. R. Rüttner: Ultrastructural study of the normal rabbit synovium. Path. et Microbiol. (Basel) 1974, 41, 283-292.

Zichner, L. \& D. Engel: Electron microscopical examination of the ultra-sonic effect on the rabbit's synovial membrane. $Z$. ges. exp. Med. 1971, 154, 1-13. 


\section{SAMMANFATTNING}

Ljus- och elektronmikroskopisk undersökning av hästens synovialmembran. En jämförande studie mellan kliniskt friska leder och leder med intraartikulär fraktur samt leder med osteochondrosis dissecans.

Synovialmembran från 23 friska leder och 9 leder med synovit till följd av intraartikulär fraktur samt 10 leder med synovit till följd av osteochondrosis dissecans undersöktes ljus- och elektronmikroskopiskt. Såväl ljusmikroskopiskt som ultrastrukturellt befanns synovialmembranet från friska hästleder visa överensstämmelse med andra djurslags. Tre typer av synovialmembran - areolärt, fibröst och adipost - samt två typer av intimaceller kunde urskiljas histologiskt. Ultrastrukturellt kunde tre typer av intimaceller urskiljas: A- och Bceller samt en intermediär celltyp. I friska leder låg dessa celler $i$ luckra förband omgivna av en lucker matrix, som ofta stod i direkt kontakt med ledhålan. I leder med intraartikulär fraktur förelåg en lindrig inflammation i synovialmembranet. En elongering och hyperplasi av intimaceller, samt en relativ ökning av A-celler iakttogs. Intimacellernas yta var förstorad till följd av cellutskott. Vidare iakttogs en ökning av vissa organeller, nämligen en hyperplasi av det endoplasmatiska retiklet och Golgi apparater i B-celler och ett ökat antall lysosomer och vesikler i A-celler. I leder med osteochondrosis dissecans var inflammationen i synovialmembranet och hyperplasin av intimaceller mera uttalade. Ultrastrukturellt förelåg också samma förändringar som $i$ föregående grupp inbegripande även en relativ ökning av antalet A-celler. Dessutom var degenerativa förändringar i intimaceller vanliga. Dessa förändringar bestod $i$ en dilatering och vesikulering av det endoplasmatiska retiklet, kondensering av mitochondrier, dilatering av kärnhöljet och avsaknad av plasma membran medförande upplösning av cellerna.

(Received February 23, 1976).

Reprints may be requested from: Hans-Erik Johansson, Department of Pathology, Royal Veterinary College, Fack, S-104 05 Stockholm 50, Sweden.

Abbrevations in the figures.

$\begin{array}{ll}\text { A } & \text { A cell } \\ \text { B } & \text { B cell } \\ \text { BV } & \text { Blood vessel } \\ \text { G } & \text { Centriole } \\ \text { Ca } & \text { Capillary } \\ \text { Cf } & \text { Collagen fibres } \\ \text { CV } & \text { Coated vesicle } \\ \text { fm } & \text { Filamentous material } \\ \text { F } & \text { Filopodium } \\ \text { Gc } & \text { Golgi complex } \\ \text { IS } & \text { Intercellular space }\end{array}$

JS Joint space

L Lipid droplet

Ly Lysosome

Ma Macrophage

Mc Mast cell

Mi Mitochondrion

N Nucleus

Ne Nuclear envelope

SLy Secondary lysosome

V Vesicle 